\title{
14. MASS MOVEMENT ALONG THE INNER WALL OF THE MIDDLE AMERICA TRENCH, COSTA RICA ${ }^{1}$
}

\author{
Miriam Baltuck, Department of Geology, Tulane University \\ Elliott Taylor, Department of Oceanography, Texas A\&M University \\ and \\ Kristin McDougall, Branch of Paleontology and Stratigraphy, U.S. Geological Survey, Menlo Park, California ${ }^{2}$
}

\begin{abstract}
The sediments of Deep Sea Drilling Project Site 565 and University of Texas Marine Science Institute Cores IG-24-7-38 to -42 taken on the landward slope of the Middle America Trench exhibit characteristics of material subject to reworking during downslope mass flow. These characteristics include a generally homogeneous texture, lack of sedimentary structures, pervasive presence of a penetrative scaly fabric, and presence of transported benthic foraminifers. Although these features occur throughout the sediments examined, trends in bulk density, porosity, and water content, and abrupt shifts in these index physical properties and in sediment magnetic properties at Site 565 indicate that downslope sediment creep is presently most active in the upper 45 to $50 \mathrm{~m}$ of sediment. It cannot be determined whether progressive dewatering of sediment has brought the material at this depth to a plastic limit at which sediment can no longer flow (thus resulting in its accretion to the underlying sediments) or whether this depth represents a surface along which slumping has occurred. We suspect both are true in part, that is, that mass movements and downslope reworking accumulate sediments in a mobile layer of material that is self-limiting in thickness.
\end{abstract}

\section{INTRODUCTION}

The movement of sediment on the continental slope is usually attributed to turbidity currents and slumping-single events to periodic emplacements of sediments as a result of mass gravity flows (e.g., Doyle and Pilkey, 1979). These mechanisms and other types of mass gravity flows (fluidized-liquidized flow, grain flow, and debris flow) classified by Middleton and Hampton (1976) can be recognized in the sedimentary record by characteristic sedimentary textures and structures (Fig. 1). Commonly these deposits have abrupt or scoured basal contacts with the underlying sediment. Other features such as grading, laminations, dish structures, grain orientation, and grain sorting are variable depending on the mechanism of emplacement. Sediments from the continental slope offshore Costa Rica (DSDP Site 565 and UTMSI cores IG-24-7-38 to -42; Fig. 2) have features similar to a grain flow deposit, but the differences suggest a more continuous mechanism of sedimentation.

Sediments recovered at Site 565 on the the Costa Rican slope are massive and generally lack grading. Although these features are common to a grain flow deposit, the textural homogeneity and paucity of sedimentary structures of the Site 565 sediments suggest a continuously operating sedimentary mechanism: downslope creep. Such a process would disrupt depositional sedimentary features and could produce fabric and textures diagnostic of large-scale sedimentary reworking.

\footnotetext{
${ }^{1}$ von Huene, R., Aubouin, J., et al., Init. Repts. DSDP, 84: Washington (U.S. Govt. Printing Office).

Addresses: (Baltuck) Department of Geology, Tulane University, New Orleans, Louisiana 70118; (Taylor) Department of Oceanography, Texas A\&M University, College Station, Texas; (McDougall) Branch of Paleontology and Stratigraphy, U.S. Geological Survey, Menlo Park, California.
}

We examined Costa Rican slope sediments from DSDP Site 565 and from five piston cores collected in 1978 during a University of Texas Marine Science Institute (UTMSI) cruise to evaluate continuous downslope mass movement as a significant mode of slope sediment transport and to identify a means of documenting this transport (Table 1). We examined seismic profiles of the slope, sediment texture and structure, physical properties, paleomagnetics, in situ and transported benthic foraminifers, and sediment fabric.

Several lines of evidence emerged from our study that indicate the effects of plastic grain flow, or creep: (1) the general lack of sedimentary structures, (2) generally homogeneous texture, (3) overconsolidation of sediment in upper part of the sediment column at Site 565, (4) scattered paleomagnetic orientations indicating a disturbed section, (5) mixed assemblages of benthic foraminifers containing both in situ fauna and species transported from upslope, (6) presence of a penetrative fabric here described as a "scaliness," and (7) high sediment accumulation rates such as might be anticipated from amassing sediment from upslope. Thus we envision a simple model of material in continuous creeping movement in the upper sediment of the slope. As transport reworks the sediment it dewaters and approaches its "plastic limit"; as sediment flow is impeded at the base of the more mobile upper meters, the sediment is plastered along the firmer underlying material. Small-scale creep could lead to slope failure and larger-scale slumping events, especially in a tectonically active area such as the Middle America Trench, where earthquake activity will contribute another mechanism for triggering these events.

\section{GEOLOGIC SETTING}

The Middle America slope is an extension of the Central American continental framework that is overlain by 
Turbidity current

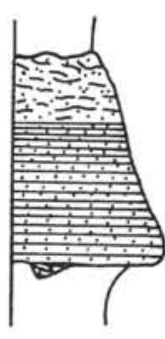

Fluidized/liquefied flow

Rippled or flat top

Ripple drift micro$x$-lamination

Laminated

Good grading

("distribution

grading")

Flutes, tool marks on base

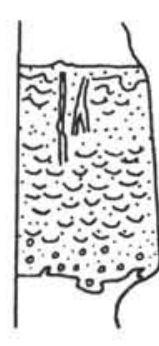

Sand volcanoes or flat top convolute lamination Fluid escape "pipes"

Dish structure?

Poor grading

("coarse tail grading")

?Grooves, flame and

load striations

structures on base
Grain flow

Debris flow

Figure 1. Structure and textures of deposits from single-mechanism mass gravity flows. No vertical scale is implied (from Middleton and Hampton, 1976).

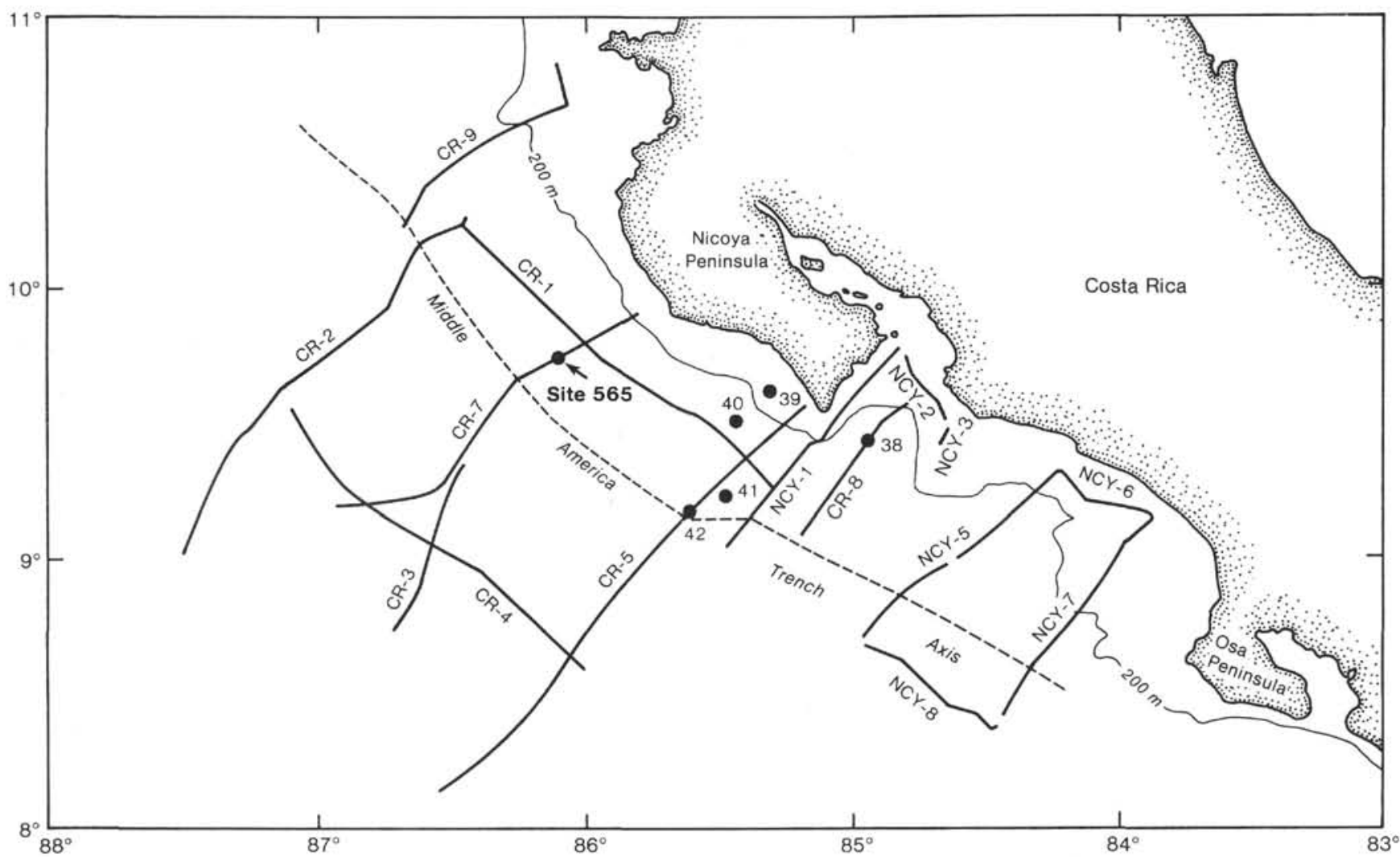

Figure 2. Location map of Site 565 and of track lines and the five piston cores collected during UTMSI Cruises IG 24 and 29.

Table 1. Site and piston core locations.

\begin{tabular}{|c|c|c|c|}
\hline $\begin{array}{l}\text { Piston core } \\
\text { or site }\end{array}$ & Latitude, longitude & $\begin{array}{l}\text { Water } \\
\text { depth } \\
\text { (m) }\end{array}$ & $\begin{array}{l}\text { Recovered } \\
\text { sediment } \\
\text { (m) }\end{array}$ \\
\hline IG-24-7-38 & $\begin{array}{l}09^{\circ} 22.4^{\prime} \mathrm{N} \\
84^{\circ} 58.1^{\prime} \mathrm{W}\end{array}$ & 1179.58 & 10.09 \\
\hline IG-24-7-39 & $\begin{array}{l}09^{\circ} 38.0^{\prime} \mathrm{N} \\
85^{\circ} 19.8^{\prime} \mathrm{W}\end{array}$ & 104.24 & 2.70 \\
\hline IG-24-7-40 & $\begin{array}{l}09^{\circ} 31.0^{\prime} \mathrm{N} \\
85^{\circ} 27.0^{\prime} \mathrm{W}\end{array}$ & 1243.58 & 6.63 \\
\hline IG-24-7-41 & $\begin{array}{l}09^{\circ} 15.5^{\prime} \mathrm{N} \\
85^{\circ} 31.2^{\prime} \mathrm{W}\end{array}$ & 2467.05 & 9.00 \\
\hline IG- $24-7-42$ & $\begin{array}{l}09^{\circ} 9.4^{\prime} \mathrm{N} \\
85^{\circ} 35.0^{\prime} \mathrm{W}\end{array}$ & 3427.17 & 4.93 \\
\hline DSDP Site 565 & $\begin{array}{l}09^{\circ} 43.69^{\prime} \mathrm{N} \\
86^{\circ} 05.44^{\prime} \mathrm{W}\end{array}$ & 3111 & 287.28 \\
\hline
\end{tabular}

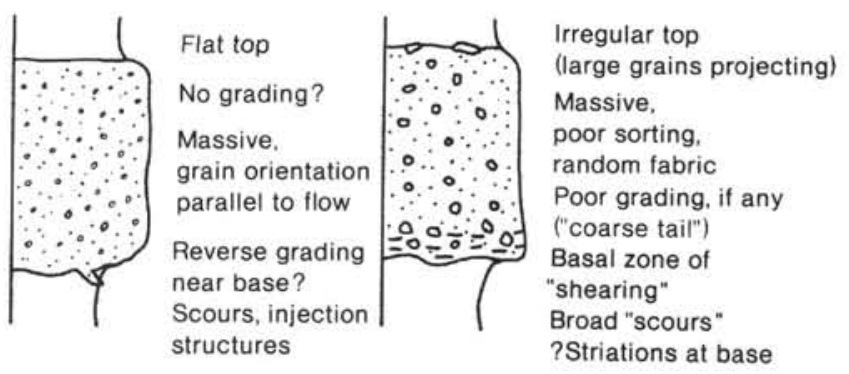

Striations at base 
ume) and calcareous nannoplankton zones Emiliana huxleyi and Geophyrocapsa oceanica (Filewicz, this volume). Similar massive Pleistocene and Miocene muds and mudstones were also encountered in the UTMSI cores. The Pleistocene assemblages correlate with planktonic foraminiferal Zone N23. The Miocene assemblage (sample IG-24-7-42, $493 \mathrm{~cm}$ ) is from a white chalk deposited at abyssal depths under oceanic conditions away from the continental margin and will not be considered further in this study. The UTMSI cores recovered 2.7 to $10.0 \mathrm{~m}$ of sediment and were drilled at depths ranging from 104 to 3427 m (Fig. 2; Table 1).

\section{SEISMIC PROFILES}

Seismic reflection profiles of the continental slope at Site 565 (UTMSI Profile CR7) appear in figures 10 and 11 of the Site 565 report (this volume). Drilling penetrated only the upper $328 \mathrm{~m}$ of slope sediment. This upper unit shows few bedding reflectors and these are laterally discontinuous and of irregular trend. Other UTMSI profiles of the Costa Rican slope show similarly disrupted bedding in the upper sediments. Thus on a large scale, seismic profiles show a lack of bedding consistent with the massiveness of the mud and mudstones recovered in cores from this site.

\section{SEDIMENT TEXTURE AND STRUCTURE}

Grain size analysis for sediments at Site 565 (Taylor and Bryant, this volume) show a silty clay texture with a gradual trend toward increased clay content with depth. There are a few distinct ash beds, and mottling and burrowing occur throughout the hole. Graded bedding (clayey silt to silty clay) and faint current laminations also occur sporadically. The sand is generally dispersed through- out the sediment rather than concentrated in specific beds. Small pebbles (under $15 \mathrm{~mm}$ in diameter) of semiconsolidated mudstone are also dispersed throughout the massive mud, a characteristic of continental margin debris flow deposits where the strength of the matrix mud prevents internal sorting or grading (Stanley and Unrug, 1972). The unsorted dispersal of sand- and siltsized grains throughout the sediment sections may be a further expression of matrix strength.

\section{PHYSICAL PROPERTIES}

A rapid change in physical properties occurs in the upper 20 to $30 \mathrm{~m}$, as indicated by a sharp decrease in water content and porosity and increase in bulk density (Fig. 3). Water content decreases from 60 to $40 \%$ from the sediment surface to $20 \mathrm{~m}$ sub-bottom. Below $20 \mathrm{~m}$ the water content decreases to about $30 \%$ at a depth of about 45 to $50 \mathrm{~m}$. Contact marked by physical properties occurs at this last depth and is indicated by an abrupt increase in water content that fluctuates around $35 \%$ to a depth of $130 \mathrm{~m}$.

The compaction of sediments under gravitational loading results in a decrease of water content and porosity with consequent increases of bulk density and shear strength. Skempton (1970) studied the rate of increasing shear strength as related to burial depth for marine sediments. He defines a range of shear strength versus effective overburden pressure that varies between 0.2 and 0.5 for sediments having undergone normal consolidation. Results of shear strength measurements of Sites 565 when plotted against effective overburden pressure yield a ratio of 0.7 . This value is slightly higher than the range defined by Skempton and possibly reflects the effect of another process, such as downslope transport and parti-

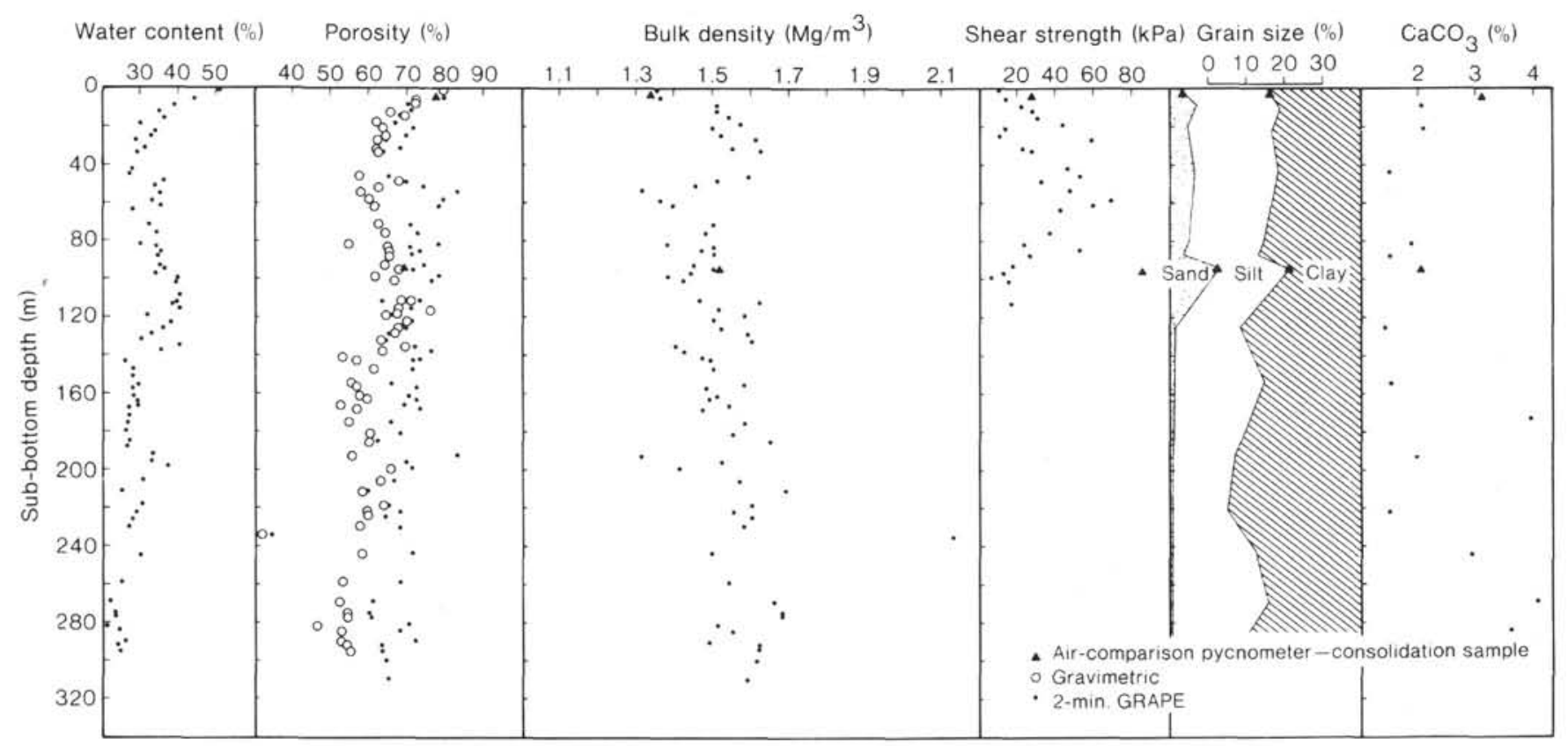

Figure 3. Downhole trend of index geotechnical properties at Site 565 (from Taylor and Bryant, this volume). Profiles of physical properties for samples from DSDP Site 565 reflect the abrupt changes occurring in sediments above an apparent contact at $40 \mathrm{~m}$. The grain size analysis profile exhibits the fairly homogenous texture of sediments recovered from this site. 
cle rearrangement, aiding in the consolidation of sediments.

Despite the lithologic homogeneity and massive appearance of the sediment, there is a distinct break in physical properties at a sub-bottom depth of 45 to $50 \mathrm{~m}$. We suspected this was related to plastic reworking of sediment during downslope creep and sought tangible evidence of sediment transport in benthic foraminiferal assemblages.

\section{PALEOMAGNETICS}

Paleomagnetic properties of the sediments at Site 565 are described in the Site 565 report (this volume). The natural remanent magnetism intensities are initially high $\left(10^{-5} \mathrm{emu}\right)$ but decrease to $10^{-6} \mathrm{emu}$ at about $20 \mathrm{~m}$ subbottom. Between 20 and $50 \mathrm{~m}$, the inclinations are scattered and the magnetic intensity decreases; from 50 to $100 \mathrm{~m}$, the intensity decreases rapidly to about $2 \times 10^{-7}$ $\mathrm{emu}$, and below $100 \mathrm{~m}$ intensity is so low that initial demagnification steps destroyed any measurable remanent magnetism. The absence of measurable magnetic inclination is attributed to the rearrangement of magnetic particles because of bioturbation, slumping, or plastic mass flow of sediments. Such mixing would be expected to destroy the original magnetic orientation, but if the sediment is sufficiently fluid to permit reorientation of magnetic particles, the remagnetization would occur in alignment with the ambient field (Verosub et al., 1979).

Experiments by Verosub et al. (1979) with sediment remagnetization indicate that the critical water content necessary to permit remagnetization is greater than the initial water content of the uncompacted sediment, that is, disturbed sediment will not remagnetize to the ambient magnetic field even if it has a high water content. The reworked sediment of the Costa Rican slope thus probably retains its original magnetic intensity and inclination in the smaller fragments of sediment created during reworking. The addition of magnetic vectors occurring in the smaller sediment fragments could result in cancellation of magnetic vectors and produce the magnetic incoherence observed in these sediments. Whether or not this occurs in the sediment at Site 565, it is interesting that trends are particularly definable in the upper 40 to $50 \mathrm{~m}$ of the section.

\section{BENTHIC FORAMINIFERS}

Transported foraminifers are common throughout Site 565 and the UTMSI cores, frequently averaging greater than $50 \%$ of the total assemblage. These assemblages indicate transport is the result of both continuous downslope movement and rapid displacement associated with slides, debris flows, or turbidity currents. This conclusion is based on biofacies analysis, which relates water masses, physical properties, water depths, and benthic foraminiferal species or assemblages with specific water depth ranges (Bandy, 1961; Ingle, 1980; Douglas, 1979, 1981; also see McDougall, this volume, for a more complete discussion of the techniques and methods used). Several biofacies may be represented in a single sample, thus, the paleobathymetry is determined by the deepest biofacies present and reflects the minimum depth of de- position. Paleoecologic interpretations are affected by selective preservation and predation, and by transport, mixing, and environmental changes. Selective preservation and predation alters the species abundances, and can be observed directly from the condition of the tests or by comparisons of species present with dissolution indexes for benthic foraminifers (Corliss and Honjo, 1981). Transport and mixing alters the composition of the assemblages. Although the effects of transport and mixing are suggested by the condition of the tests, they are more easily detected along with environmental shifts by changes in diversity, concentrations of small or similar-sized specimens, or changes in the biofacies patterns. Changes in the biofacies patterns include offsets or lobes of a particular biofacies (Bandy, 1961; Douglas, 1979, 1981; Ingle, 1980). Peak abundances expressed graphically as lobes of shallower water species (Fig. 5) in one or two samples indicate slides or debris flows, whereas offsets or large-scale changes in biofacies abundances tend to reflect environmental shifts or more continuous downslope movement. The Pleistocene section of DSDP Site 565 and the UTMSI cores contain examples of both modes of transport, but a slow gradual downslope movement appears to have been the dominant mechanism.

Biofacies analysis of the UTMSI cores indicates in most cases that there has been little change between the late Pleistocene and the present site of deposition (Figs. 4, 5; Table 2). An environmental change is noted in Core 41 between samples at 300 and $500 \mathrm{~cm}$. Foraminifers suggest that deposition occurred in the abyssal biofacies for samples 500 to $900 \mathrm{~cm}$, and in the lower bathyal biofacies for samples 100 to $300 \mathrm{~cm}$. Although decreasing water depths cannot be discounted, the faunal change in Core 41 between 300 and $500 \mathrm{~cm}$ is believed to result from an adjustment of the water masses, following maximum glaciation.

Overall, the biofacies in the UTMSI cores indicate a gradual and continuous downslope movement of benthic foraminiferal faunas (Fig. 5). Shallower water biofacies are represented in each of the cores, but the abundance generally decreases with water depth. There is an increase in abundance of shelf species in core IG-24-7-42, which may be the result of ponding of sediment at the base of the slope and in the Trench. The only inner shelf species that reach the slope are several specimens of Quinqueloculina lamarkiana. These are broken and worn, indicating transport. Outer shelf, upper bathyal, and oxygen minimum zone species that reach the lower slope include platelike forms such as Bolivina bicostata and Epistominella bradyana or fragile thin-walled specimens of Chilostomella oolina and Globobulimina pacifica. All these species have probably been transported in the water column rather than within the sediment, because the tests are easily suspended and are too fragile to withstand much transport. The larger, heavier tested forms such as Cassidulina, Hoeglundina, and Gyroidina present in the lower slope assemblages often have fragmented or worn tests. The living range of these species (Uchio, 1960; Smith, 1964) indicates some transport was necessary to move these species downslope, but may not have been as great as indicated by the biofacies anal- 


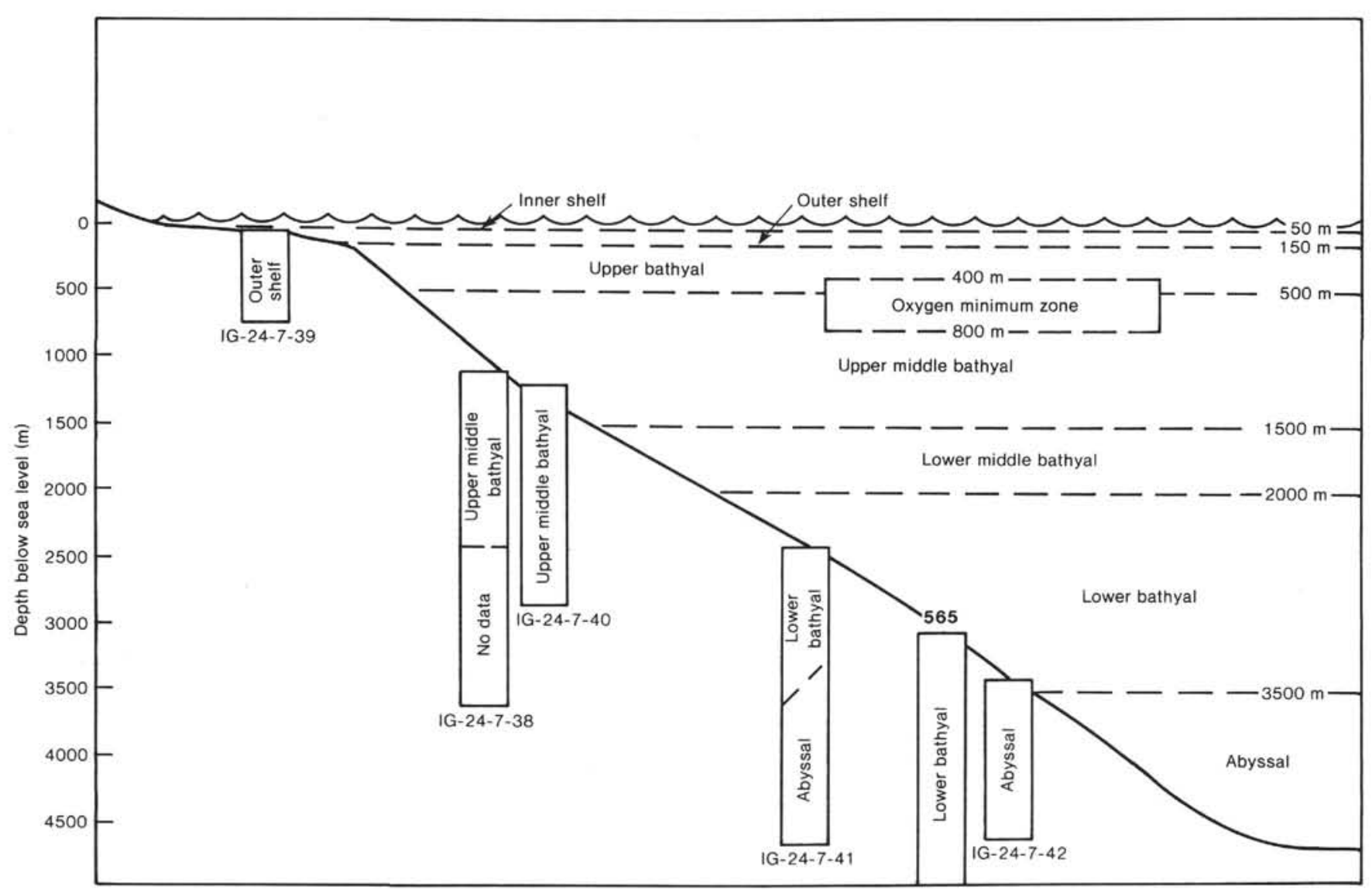

Figure 4. Location of UTMSI piston cores with respect to present benthic foraminiferal biofacies. Depth ranges for the biofacies are taken from studies of recent foraminiferal faunas and physical-chemical properties off Central America (see McDougall, this volume, for discussion and references).

ysis, which considers primarily the upper depth limit of a species. The condition of most of the tests suggests transport occurred as part of the sediment load.

Benthic foraminiferal assemblages from Site 565 (Table 3 ) indicate deposition occurred within the lower bathyal and abyssal biofacies with paleodepths close to $4000 \mathrm{~m}$ and under the influence of both the Pacific Deep Water (PDW) and Antarctic Bottom Water (AABW). Major changes in the benthic foraminiferal faunas correspond to the glacial-interglacial cycles of the late Quaternary and to changes in the water masses. Glacial conditions (cold events, Fig. 6) are correlated with events dated at 0.7 (Core 565-2), 0.9 (Core 565-6), and 1.2 to 2.5 (Cores 565-7 to 565-10) Ma (Ingle, 1967, 1973; Kent, Opdyke, and Ewing, 1971; Bandy, 1972; Olsson, 1974; Shackleton and Opdyke, 1977; Keller and Ingle, 1981). Dissolution associated with the cold events (e.g., Pliocene/Pleistocene boundary, 1.2 to $2.5 \mathrm{Ma}$ cold event) is believed to be the result of expansion of the cold AABW during the glacial maxima. In Cores 565-1, the onset of the warm event and associated transgression is accompanied by a decrease in water depths or more probably an adjustment of the water masses as the production of the AABW declines. Taxonomic notes and paleoenvironmental considerations for Site 565 species are given in McDougall (this volume), and age and paleoceanographic interpretations are discussed by Filewicz, by Stone and Keller, and by McDougall (this volume) and are summarized in Figure 6.

Transported fauna are common throughout the Pleistocene and average at least $50 \%$ of the fauna. Biofacies patterns indicate transported faunas are present as a result of two kinds of downslope movement: a rapid single event (mass gravity flow) usually affecting one biofacies; and a continuous downslope movement, which effects all biofacies. Specimens transported during intervals of rapid downslope movement include platelike bolivinids from the outer shelf-upper slope, cylindrical forms such as Buliminella and Chilostomella from the upper slope. Abundances of these species are anomalously high in some samples, suggesting rapid downslope movement such as in Sections 565-2-2, 565-2-5, and 565-2-6; 565-3-5; and 565-4-1 (Fig. 6). The larger, more robust transported specimens in these samples tend to be from the adjacent shallower water biofacies and/ or have broken or altered tests (molds, fillings, or overgrowths). Continuous downslope transport is recognized by the broader more consistent abundances of biofacies faunas common throughout the Pleistocene (Fig. 6). Transported foraminifers in these intervals include a variety of shapes, sizes, and states of preservation. Shallower water species are represented by continuous low abundances rather than by sporadic peak abundances. Similar patterns were noted in the UTMSI cores. 
IG-38

IG-40

IG-41

IG-42
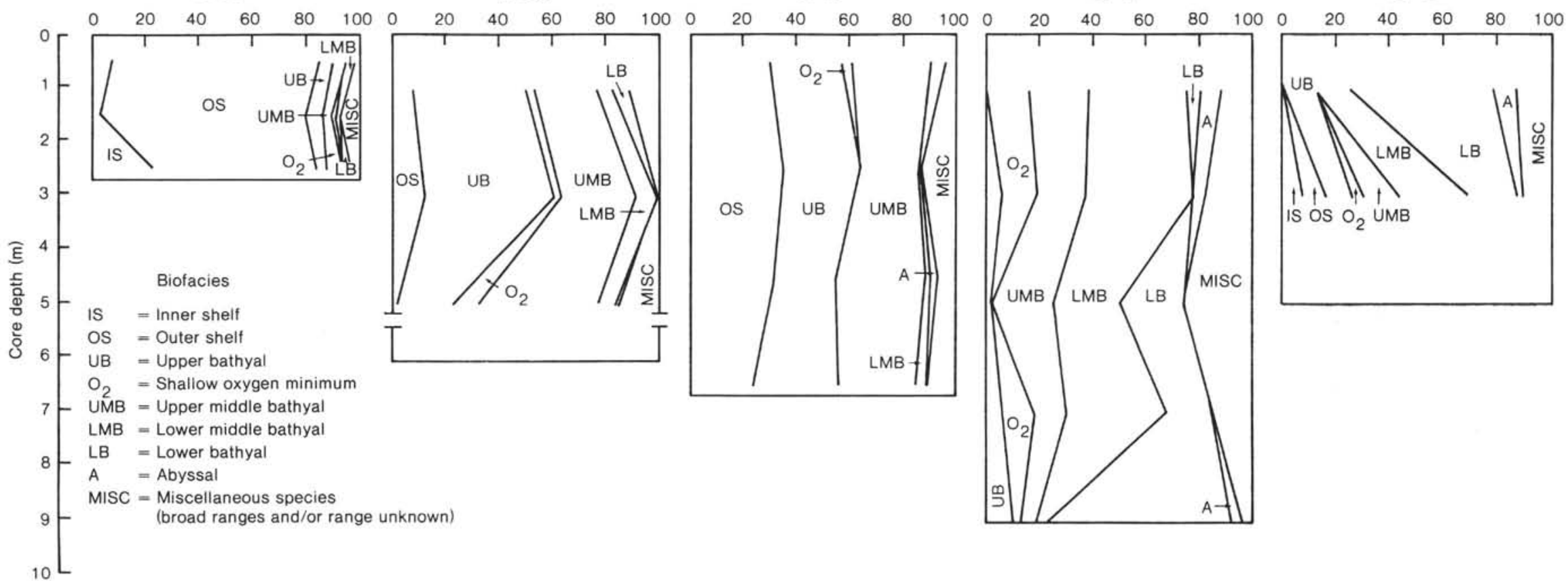

Figure 5. Biofacies trends for the UTMSI cores based on benthic foraminifers. Cores are arranged from shallowest (IG-24-7-39) to deepest (IG-24-7-42). Biofacies groups are the percent of specimens with upper depth limits in that biofacies (Table 2). The distribution and abundance of each biofacies in the IG cores indicate that deposition occurred in the outer shelf (Core IG-24-7-39), upper middle bathyal (Cores IG-24-7-38 and IG-24-7-40), lower bathyal (Core IG-24-7-41, samples at 100 and $300 \mathrm{~cm}$ ), and abyssal (Cores IG-24-7-41, samples at 500, 700, and 900 cm, and IG-24-7-42). 


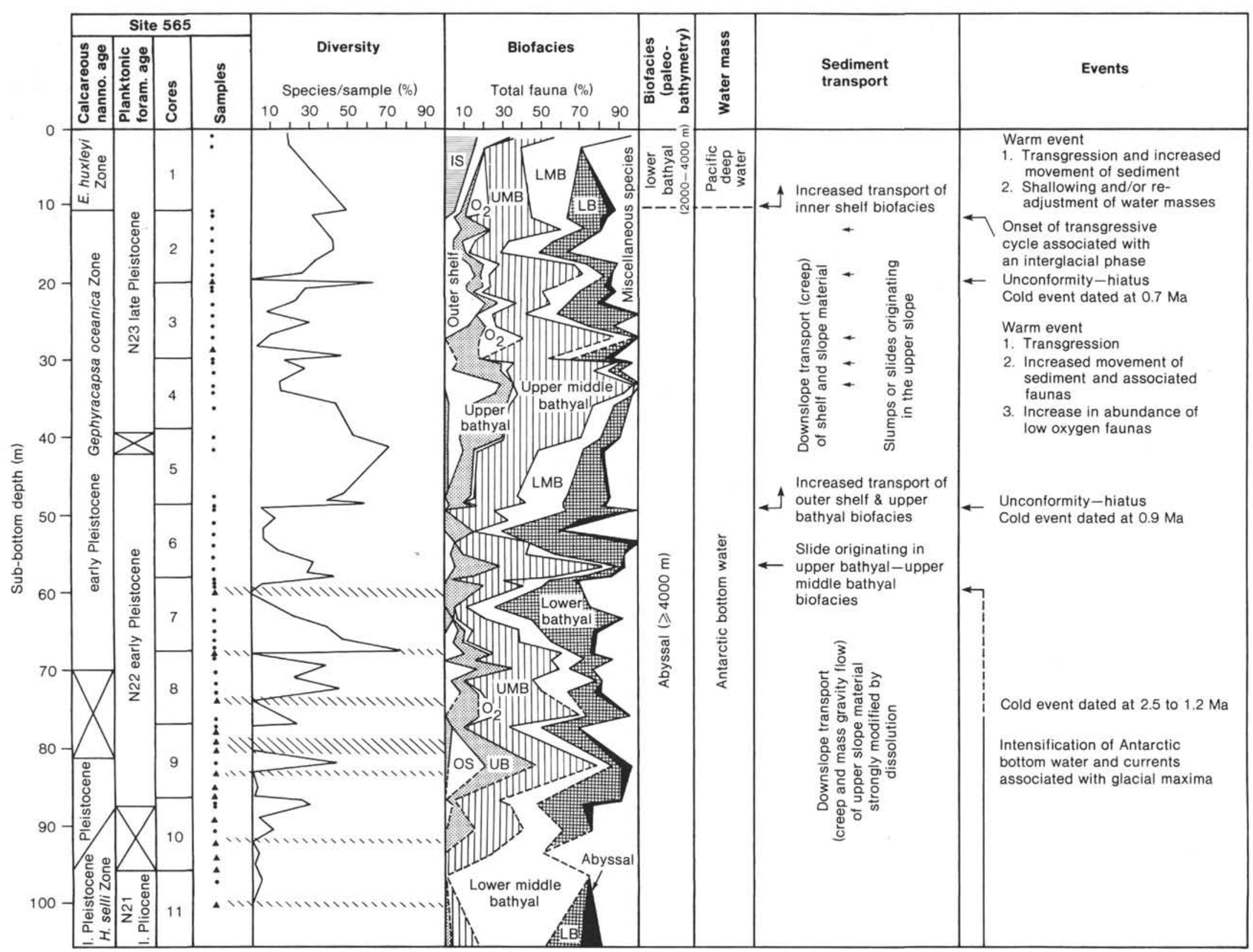

Figure 6. Biofacies and diversity trends for the Pleistocene benthic foraminiferal assemblages of Site 565. Solid triangles (sample column) and hachured lines (diversity column) indicate poorly preserved or barren samples. Diversity and biofacies are based on counts of $300 \pm$ specimens where possible. Biofacies groups are the percent of specimens with upper depth limits in that biofacies (McDougall, this volume). Biofacies present in this core range from the inner shelf to abyssal. Depth ranges and symbols for the biofacies are given in the previous figures (Figs. 4 and 5) and in Table 2. Age and ecologic interpretations are from Filewicz; McDougall; and Stone and Keller (this volume). 
Table 2. Faunal list, UTMSI cores.

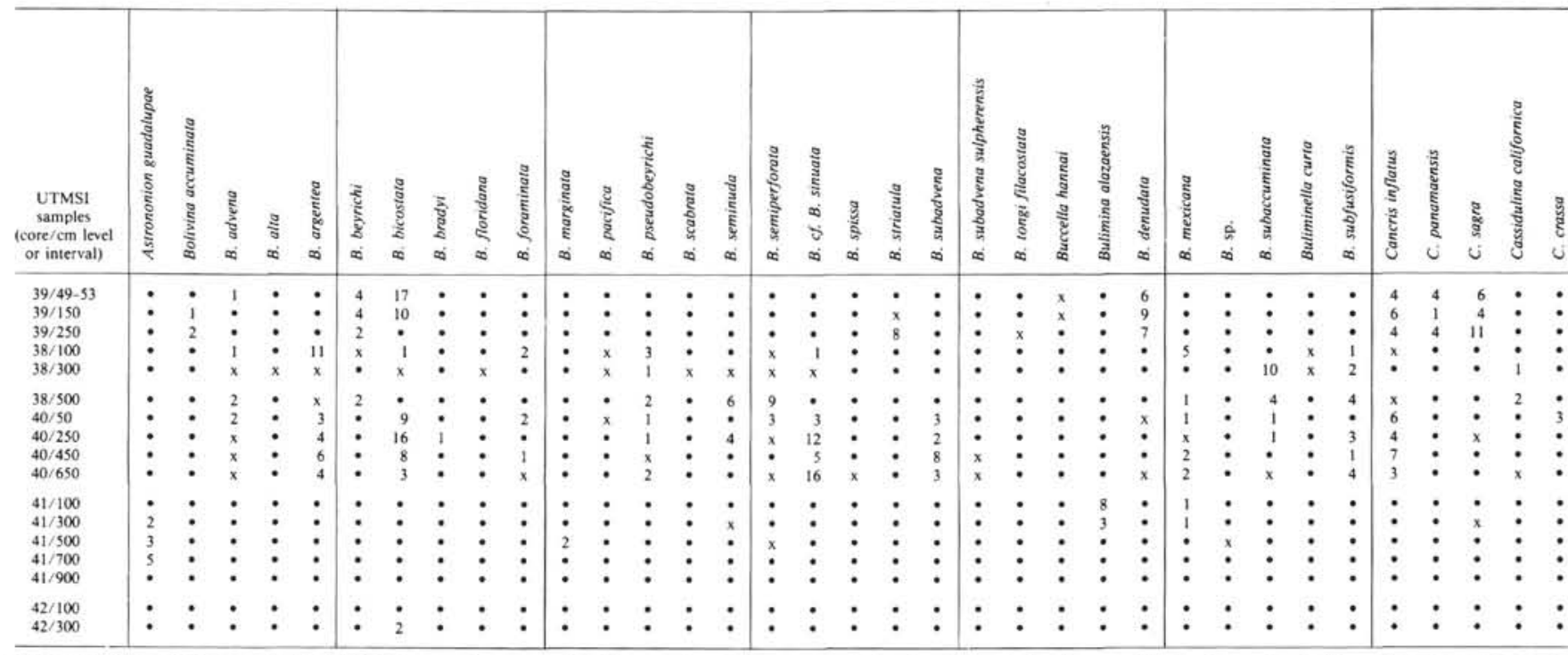

Note: Benthic foraminiferal occurrences for the UTMSI cores are given as percent total fauna, and an $\mathrm{x}$ indicates a percent of less than I. Biofacies abundances are also given in percent of total fauna. Dot indicates species is not present.

\section{SEDIMENT FABRIC}

In contrast to the general uniformity of sediment texture at Site 565, a penetrative fabric best described as a "scaliness" occurs in several intervals of mud and mudstone. The fabric is a primary sedimentary feature rather than a product of drilling disturbance, for it is observed over a range of consolidation from firm mud to undisturbed mudstone blocks in a matrix of drilling-disturbed mud. This fabric was observed in the near-surface sediments recovered in the UTMSI cores as well as at subsurface depths well below $150 \mathrm{~m}$ at Site 565 .

The scaliness is horizontal to subhorizontal; mud breaks into smooth "polished" concoidal flakes of less than $2 \mathrm{~mm}$ in length. Figure 7 illustrates scaly splitting of firm mud. The scaly fabric is striking under very high magnification. Small (under 2-mm) pieces of scaly mud and mudstones were selected from the Site 565 sediments for examination under the scanning electron microscope (SEM). Figure 8A-D shows SEM photographs from this study. Flakes of a montmorillonite clay are aligned in larger stacks incorporating small blocky fragments of other materials. Such alignment is an expected feature of clays because of their phyllosilicate crystalline structure (Burst, 1976), but the size of aligned flakes indicates an aglomeration of clay crystals. In a continental slope setting, current activity could be an agent of earlier horizontal orientation of the clayey sediment, but the incorporation of blocky fragments in the clayey stacks belies sorting and aligning by current activity.

Downslope creep and scaly fabric are described in some soil science texts (e.g., Jackson, 1969), and we suggest that this process occurs here on the Costa Rican slope. Plastic mass flow of sediments downslope would continuously rework materials into a closer-knit fabric, smearing clayey sediment into alignment and grinding other fine materials into the clayey base. Dewatering during this movement would result in the overconsolida- ted sediment near the top of the sediment column observed at Site 565 . On a broader scale, such flow destroys sedimentary bedding, resulting in the massivity evidenced in the seismic profile of the upper unit at Site 565 as well as in the cores recovered at the site.

\section{DISCUSSION OF SEDIMENTARY PROCESSES}

The upper 45 to $50 \mathrm{~m}$ of sediment at Site 565 are lithologically indistinguishable from sediment recovered at greater depths downhole: the entire $328 \mathrm{~m}$ is placed in a single lithologic unit. Geotechnical and paleomagnetic properties, however, suggest that different processes are presently occurring in the upper part of the section, and sedimentologic and faunal characteristics suggest that these are related to downslope transport and mixing of sediment.

The unique structure of the upper sedimentary section at Site 565 provides us with the opportunity to try several approaches of characterizing or recognizing a gradual, downslope transport mechanism. The fact that sediments posses different rheological behaviors and shear strength characteristics and rest on various degrees of slopes on continental margins and slopes leads to the conclusion that downslope transport mechanisms can vary from a slow, downslope creep to slumps, debris flows, or turbidity currents. Any one of these transport mechanisms can in turn be the precursor of subsequent catastrophic failures.

The nature of a deposit undergoing mass movement is dependent on the strength characteristics of the sediment resisting the gravitational impulse acting on the pile along a given inclined plane. The possibility of frequent seismic disturbance in the region of the Middle America Trench suggests the gravitational impulse may occasionally be bolstered by stresses resulting from seismic activity. The presence of excess pore pressure generated downhole at Site 565 (see Site 565 report, this volume) may result from the subduction process burying 


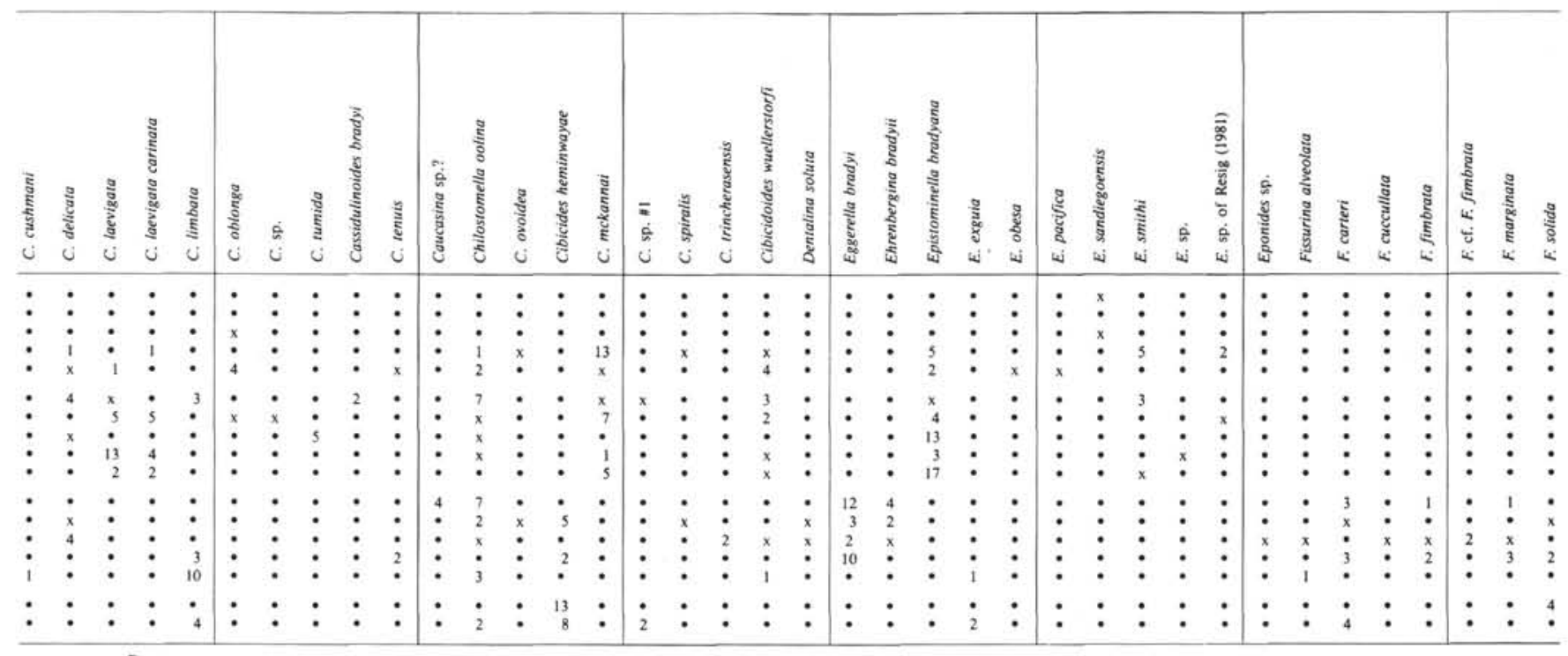

sediment of both the oceanic plate and slope deposits. Excess pore pressure produces a decreased effective stress within the sedimentary column. Upon reduction of the effective stress, the sediment loses its shear strength, which in turn may lead to failure even on slopes as gentle as $1^{\circ}$ (Prior and Coleman, 1981).

Movement within the sediment mass would tend to rearrange particles (fabric) and aid in compacting a given unit. This rearrangement would be reflected in quickly changing physical properties in the affected zone. A rapid decrease of index properties with a normally consolidating sediment is not unusual. Porosity-depth relationships presented by Hamilton (1976) reflect a 5\% decrease in porosity in the upper $40 \mathrm{~m}$ for calcareous sediments, $2 \%$ for diatomaceous ooze, and approximately $3 \%$ for terrigenous sediments. Bryant et al. (1981) present other porosity-depth profiles showing a wide variety of values for the reduction of porosity in the upper $20 \mathrm{~m}$, ranging from a decrease in porosity of $2 \%$ for a $75 \%-\mathrm{CaCO}_{3}$ sediment with 35 to $55 \%$ sand-size grains to a change in porosity of $14 \%$ for a 10 to $15 \%-\mathrm{CaCO}_{3}$ sediment with $80 \%$ clay-size grains. These same profiles show an expected $6 \%$ decrease in porosity for a 5 to $20 \%-\mathrm{CaCO}_{3}$ sediment with $60 \%$ clay-size grains in a 20 -m-interval surface. Site 565 has a composition similar to this latter sediment, and porosity values here drop from a surface high of 80 to $66 \%$ at $19 \mathrm{~m}$, a change of $14 \%$ in less than $20 \mathrm{~m}$. This rapid decrease of porosity and increase in bulk density at Site 565 indicates a forced dewatering process.

Atterberg limits for Site 565 sediments yield two different classifications on the Casagrande Plasticity Chart (fig. 4, in Taylor and Bryant, this volume). The uppermost sample from Section 565-1-4 is classified as an inorganic clay of medium to high plasticity, whereas the sample from Section 565-1-4 is classified as an inorganic clay of medium to high plasticity, whereas the sample from Section 565-10-6 is defined as a micaceous or diatomaceous fine sand and silt of high plasticity. Sediment clas- sification using Atterberg limits reflects rheological behavior more than sediment composition. The similarity of composition of these two samples has already been noted in this chapter, and their rheological character can be appreciated in figure 4 of Taylor and Bryant (this volume). The shift of the natural water content with depth takes the sediment from a state near its liquid limit (120$140 \%$ ) for surface and shallow sediment to one approaching the plastic limit $(60-70 \%)$. The rheological character of the sediment is one in which the sediment behaves less plastically with depth until the natural water content becomes less than the plasticity index. The Atterberg limits at Site 565 reflect the near fluid nature of section 565-1-4 and the practical plastic limit of sediments in section 565-10-6.

Moreover, because of the textural and lithologic homogeneity of sediment at Site 565 we can compare the liquid and plastic limits determined for these sediments with the decreasing water content downcore (Fig. 9). The water content steadily decreases from above the liquid limit to below the plastic limit at about 45 to $50 \mathrm{~m}$, then increases below this depth to a fairly constant value just above the plastic limit that was determined for these sediments.

The truncation of the layer of increasing shear strength and bulk density at approximately $50 \mathrm{~m}$ defines a zone of presently more active sediment movement. A state of overconsolidation for this unit reflects the dewatering process associated with downslope movement. Booth (1979) recognized flow deposits in the Gulf of Mexico from the appearance of an overconsolidated sediment with low water contents overlying a normal to underconsolidated section below. It would appear that Site 565 fulfills these observations. The injection of pore water from the zone of movement into the uppermost layers will decrease the apparent state of consolidation of these latter sediments and produce higher water contents, thus decreasing the effective normal stress. These 
Table 2. (Continued).

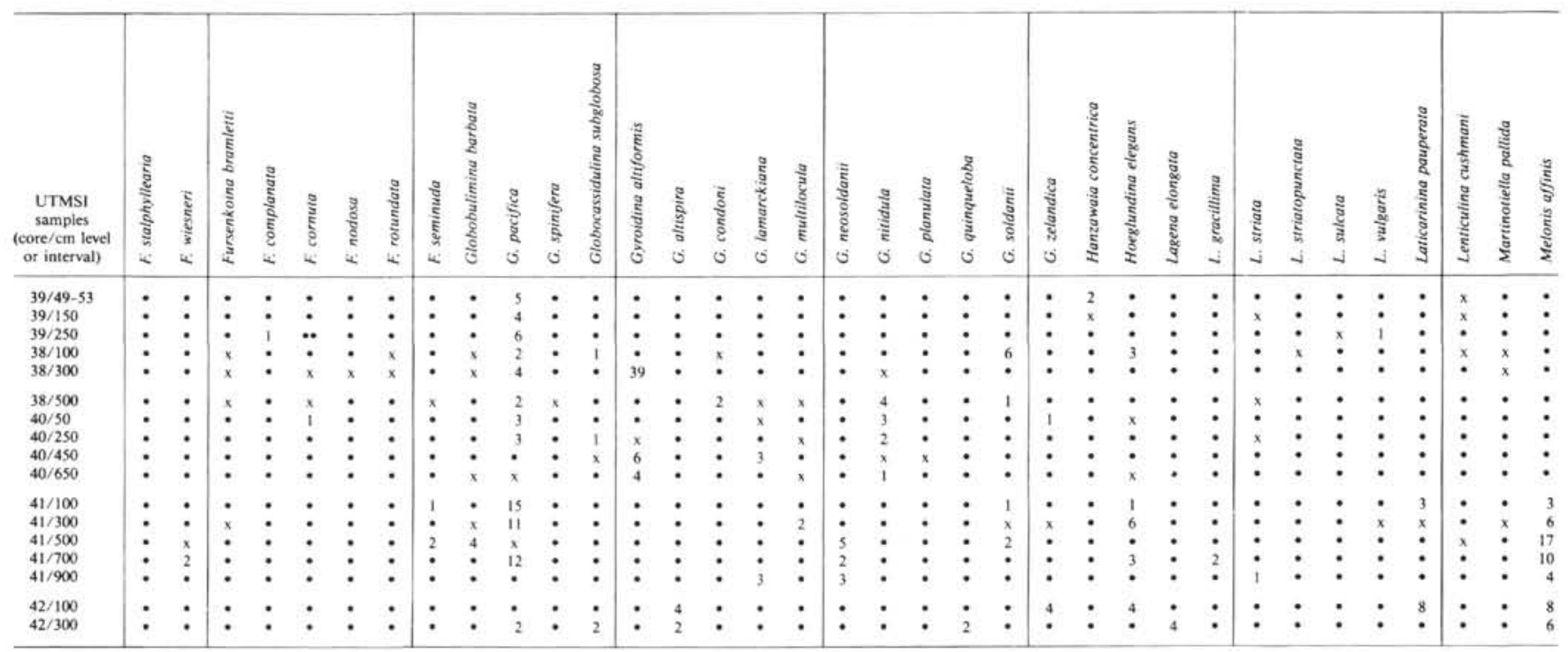

higher water contents, in turn, shift the rheological nature of the sediment toward a more fluid state such as measured in Section 565-1-4.

Lowe (1979) describes sediment gravity flows in terms of the rheological nature of the deposit. The range of water contents within the liquid-plastic behavior field defined by Atterberg limits for sediments at Site 565 supports the idea of a spectrum of downslope transport processes, going from a viscous creep movement near the base of the $45-\mathrm{m}$ layer to mud flows or cohesive debris flows near the surface.

An illustration of the velocity profile resulting from the envisioned downslope movement mechanism is shown in Figure 10. Conditions defining this velocity profile set the depth of minimum velocity at $47 \mathrm{~m}$, but the point of the figure does not depend on halting the flow entirely. The sediment at the base of this mobile 45 to $50 \mathrm{~m}$ is moving much more slowly than the more fluid overlying materials: essentially it is left behind by the faster-moving upper layer. At this level in the sediment section, sediment water content has decreased to below its plastic limit (Fig. 9), providing a second indication that this material will no longer flow.

The nature of the boundary at about $47 \mathrm{~m}$ is of interest. The boundary could represent a slowly shifting horizon of sediment accumulation, where overlying clayey sediment is continuously plastered onto it as the sediment reaches its plastic limit. Smearing of clayey sediment could result in a relatively impermeable layer, effectively sealing the upper sediments from the section below. Thus buildup of pore pressure resulting from dewatering of the subducting sediments of the Cocos Plate or from formations of gas hydrates ubiquitous to the sediments on this continental slope (see Organic Geochemistry section, Site 565 report, this volume) could occur in the sediments below the zone of downslope creep. Alternatively, this layer of abrupt change in physical properties could indicate the basal surface of a slump.
Buildup of a pile of sediment too consolidated for plastic flow at its base could result in slope instability and local failure through slumping. This can be enhanced by the buildup of pore pressure at the base of the layer acting to lubricate the slump surface. A shift in the benthic foraminiferal biofacies and diversity at about $47 \mathrm{~m}$ subbottom indicates a slight unconformity or hiatus (Fig. 6), which supports the possibility of a slump surface at this depth.

We consider the answer to lie in a combination of these alternatives where mass movement and downslope reworking accumulates sediment in a mobile layer of material that is self-limiting in its thickness. At the base of the layer shearing and reworking accretes the clayey material to underlying slope sediments, creating a low permeability boundary of nonflowing clayey sediment that seals the mobile layer from the underlying material. Buildup of pore pressure below and accumulation of a thick pile of sediment above leads to local instability and slumping along the surface. The few laterally discontinuous reflectors in seismic profiles of the Costa $\mathrm{Ri}$ can slope may represent ancient slump surfaces.

Canyon sedimentation on continental slopes is generally treated in terms of depositional events such as turbidity flows, slumps, or debris flows, but continuous sedimentation processes that could lead to these events are somewhat neglected. The muds and mudstones of the Costa Rican slope are typical hemipelagic deposits of an active margin inner slope cut many canyons. The texture and fabric of sediment in this geologic setting leads us to suggest that downslope creep is a process of sediment transport of greater importance than has been heretofore recognized.

Analysis of benthic foraminiferal assemblages and detection of scaly fabric can be useful documentation of downslope creep, and shifts in physical properties and the paleomagnetic record may be used to define the layer of sediment movement. 
Table 2. (Continued).

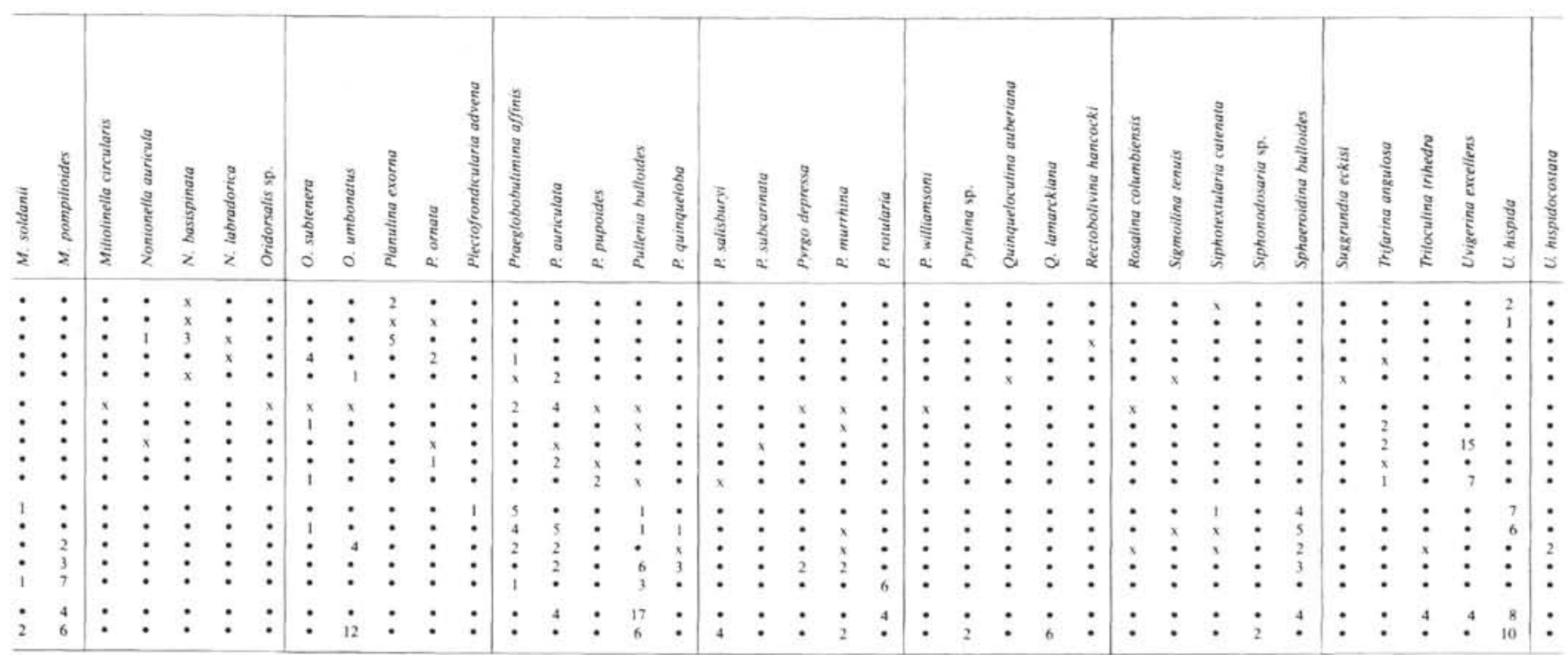

Table 2. (Continued).

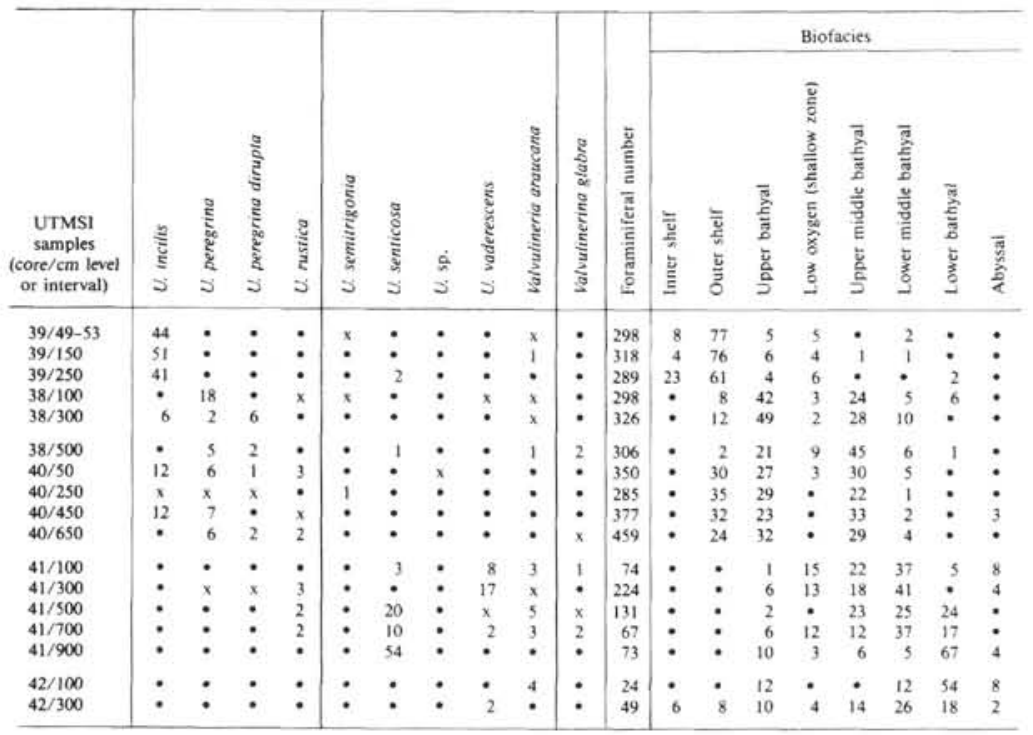

\section{ACKNOWLEDGMENTS}

We thank Dick Buffler and William Behrens for permission to examine and sample UTMSI Cores IG-24-7-38 to -42, Bill Sliter and Homa Lee for their thoughtful and thorough reviews of this paper, and Neil Lundberg for thought-provoking conversation on the subject of plastic mass flow as a mechanism of downslope sediment transport.

\section{REFERENCES}

Bandy, O. L., 1961. Distribution of foraminifera, radiolarian, and diatoms in sediments of the Gulf of California. Micropaleontology, 17:1-26.

1972. Neogene planktonic foraminiferal zones, California and some geologic implications. In Lipps, J. H. (Ed.) Eastern Pacific Plankton Biostratigraphy and Paleoecology, Paleogeogr. Pa leoclim. Paleoecol., 12:131.

Booth, J. S., 1979. Recent history of mass-wasting on the upper continental slope, northern Gulf of Mexico, as interpreted from the consolidation states of the sediment. Soc. Econ. Paleontol. Mineral. Spec. Publ., 27: 153-164.
Bryant, W. R., Bennett, R. H., and Katherman, C. E., 1981. Shear strength, consolidation, porosity and permeability of oceanic sediments. In Emiliani, C. (Ed.), The Sea (Vol. 7): New York (Interscience), 1555-1615.

Burst, J. F., 1976. Argillaceous sediment dewatering. Ann. Rev. Earth Sci., 4:293-318.

Corliss, B. H., and Honjo, S., 1981. Dissolution of deep-sea benthonic foraminifera. Micropaleontology, 27:356-378.

Douglas, R. G., 1979. Benthic foraminiferal ecology and paleoecology: a review of concepts and methods. In Lipps, J. H., et al. (Eds.), Foraminiferal Ecology and Paleoecology, Short Course No. 6: Tulsa (Soc. Econ. and Paleontol Mineral.), pp, 21-53. 1981. Paleoecology of continental margin basins: a modern case history from the borderland of southern California. In Lipps, J. H., et al. (Eds.), Depositional Systems of Active Continental Margin Basins: Short Course Notes: Los Angles (Pacific Section, Soc. Econ. Paleontol. Mineral.), pp. 121-156.

Doyle, L. J., and Pilkey, O. H., 1979. Geology of Continental Slopes: Tulsa (Soc. Econ. Paleontol. Mineral.).

Hamilton, E. L., 1976. Variations of density and porosity with depth in deep sea sediments. J. Sed. Petrol., 46:280-300. 
Ingle, J. C. Jr., 1967. Foraminiferal biofacies variation and the Miocene/Pliocene boundary in southern California. Bull. Am. Paleontol., 52:217-394.

1973. Neogene foraminifera from the northeastern Pacific Ocean, Leg 18 DSDP. In Kulm, L. D., von Huene, R., et al., Init. Repts. DSDP, 18: Washington (U.S. Govt. Printing Office), 517-567.

1980. Cenozoic paleobathymetry and depositional history of selected sequences within the southern California continental borderland. In Sliter, W. V., (Ed.), Studies in Marine Micropaleontology and Paleoecology: A Memorial Volume to Orville L. Ban$d y$, Cushman Found. Foram. Res. Spec. Publ., 19:163-195.

Jackson, M. L., 1969. Soil Chemical Analysis-Advanced Course (2nd ed., 8th Printing, 1973): Madison, Wisconsin (Dept. of Soil Science, Univ. of Wisconsin).

Keller, G. 1978. Late Neogene planktonic foraminiferal biostratigraphy and paleoecology of the northeastern Pacific: evidence from DSDP Sites 173 and 310 at the North Pacific Front. J. Foraminif. Res., 8:332-349.

Keller, G., and Ingle J. C., 1981. Planktonic foraminiferal biostratigraphy, paleoceanographic implications, and deep sea correlations of the Pliocene-Pleistocene Centerville Beach Section, Northern California. Geol. Soc. Am. Spec. Pap., 184:127-136.

Kent, D., Opdyke, N. D., and Ewing, M., 1971. Climatic change in the North Pacific using ice rafted detritus as a climatic indicator. Geol. Soc. Am. Bull., 82:2741-2754.

Lowe, D. R., 1979. Sediment gravity flows: their classification and some problems of application to natural flows and deposits. Soc. Econ. Paleontol. Mineral. Spec, Publ., 27:75-82.

Middleton, G. V., and Hampton, M. Z., 1976. Sediment gravity flows: mechanism of flow and deposition. In Turbidites and Deep Water Sedimentation, Short Course: Los Angeles (Pacific Section Soc. Econ. Paleontol. Mineral.), pp. 1-38.

Olsson, R. K., 1974. Pleistocene paleoceanography and Globigerina pachyderma (Ehrenberg) in Site 36, DSDP, Northeastern Pacific. J. Foraminif. Res., 4:47-60.

Prior, D. B., and Coleman, J. M., 1981. Resurvey of active mud slides, Mississippi Delta. Geo-Marine Lett., 1:17-21.

Shackleton, N. J., and Opdyke, N. D., 1977. Oxygen isotope and paleomagnetic evidence for early Northern Hemisphere glaciation. Nature, 270:216-219.

Skempton, A. W., 1964. Long-term stability of clay slopes. Geotechnique, 14:77.

1970. The consolidation of clays by gravitational compaction. J. Geol. Soc. London, 125:373-411.
Smith, P. B., 1964. Ecology of benthonic species. U.S. Geol. Surv Prof. Paper, 429B:B1-B55.

Stanley, D. J., and Unrug, R., 1972. Submarine channel deposits, fluxoturbidities and other indicators of slope and base of slope environments in modern and ancient basins. In Rigby, J. K., and Hamblin, W. K. (Eds.), Recognition of Ancient Sedimentary Environments: Soc. Econ. Paleontol. Mineral. Spec. Publ., 16:287-340.

Uchio, T., 1960. Ecology of living benthonic foraminifera from the San Diego, California area. Cushman Found. Foram. Res. Spec. Publ., 5:1-71.

Verosub, K. L., Ensley, R. A., and Ulrick, J. S., 1979. The role of water content in the magnetization of sediments. Geophys. Res. Lett., $6: 226-228$.

Yen, B. C., 1969. Stability of slopes undergoing creep deformation. $J$. Soil. Mech. Found. Div. Am. Soc. Civ. Eng., 95:1075-1096.

Date of Initial Receipt: 10 February 1984

Date of Acceptance: 4 May 1984

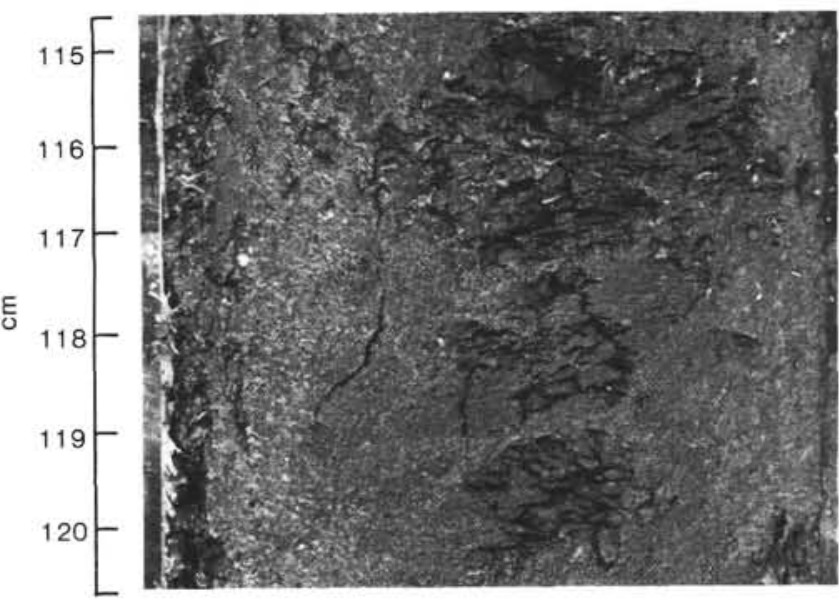

Figure 7. Typical scaly sediment fabric observed at Site 565, Sample $565-16-4,115-120 \mathrm{~cm}$ 


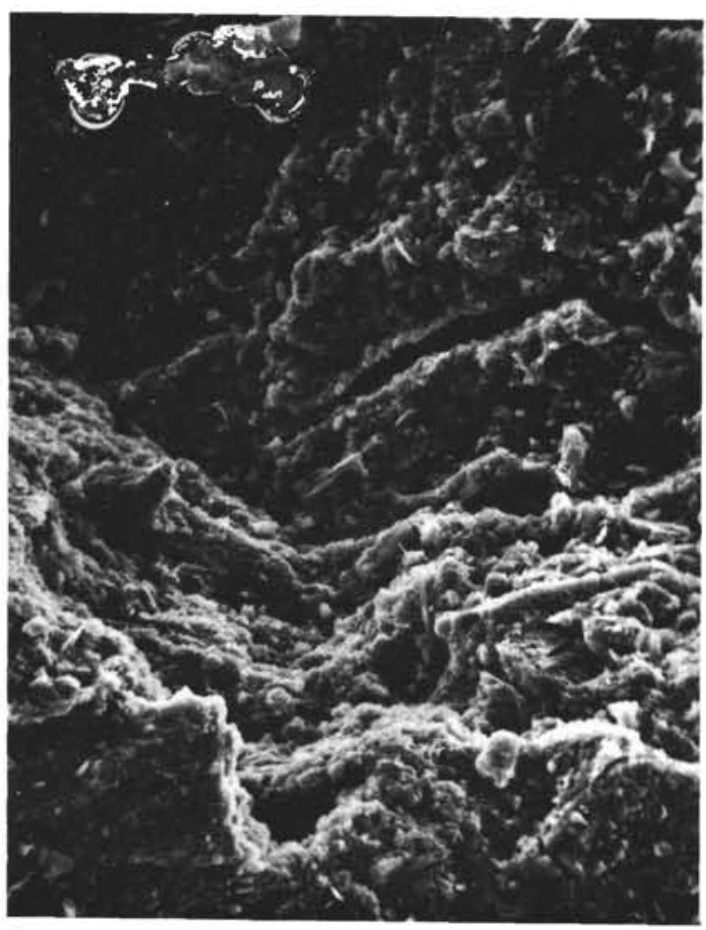

A

$50 \mu \mathrm{m}$

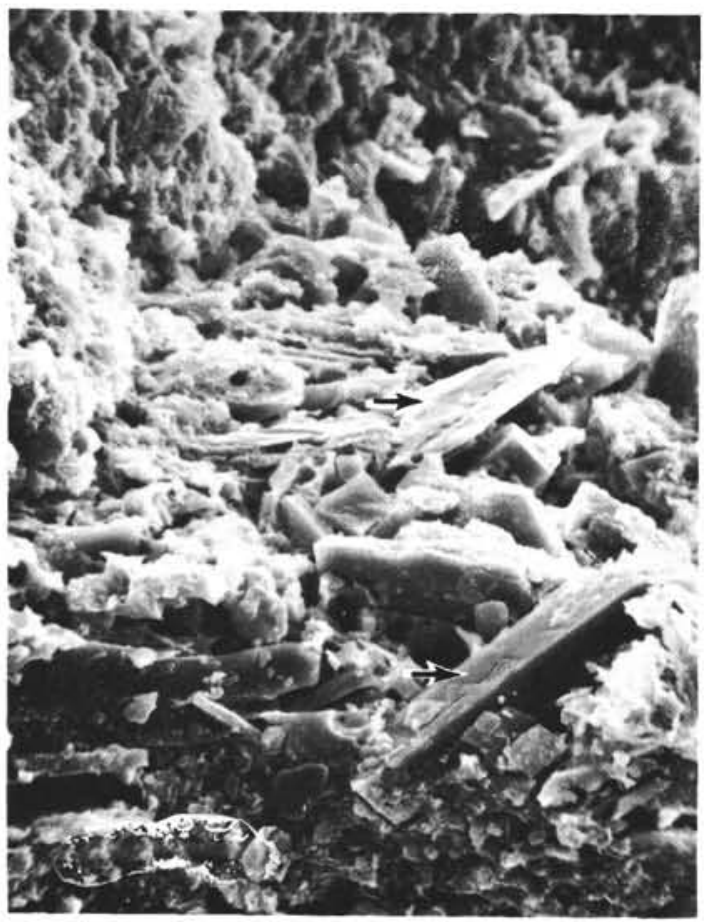

C

$25 \mu \mathrm{m}$
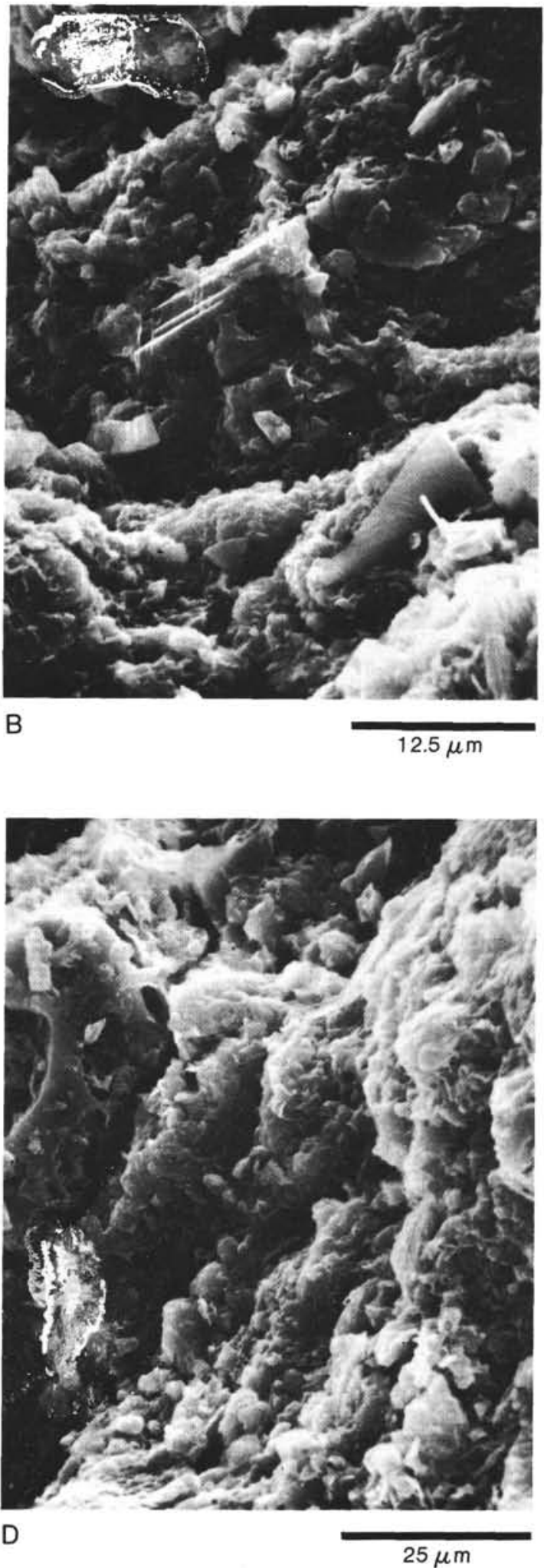

Figure 8. Scanning electron microscope photomicrographs of scaly mud from Site 565 . A. Sample $565-11-2,125 \mathrm{~cm}$. Stacks of clayey sediment incorporating blocky fragments of other sediment constituents including shell fragments. B. Sample 565-11-2, $125 \mathrm{~cm}$. Closer view of the aligned stacks of Figure 8A, illustrating the agglomerate nature of the aligned stacks of sediment. Large crystalline plugs are incorporated into layers of smaller flakes. C. Sample 565-11-2, $52 \mathrm{~cm}$. Tabular and cubic (pyrite?) crystals in clayey stacks. Arrows indicate incipient splitting of larger crystals possibly in response to shearing. D. Sample 565-11-2, $52 \mathrm{~cm}$. Multiple layers with large-scale stacks. 
Table 3. Faunal list, Site 565 .

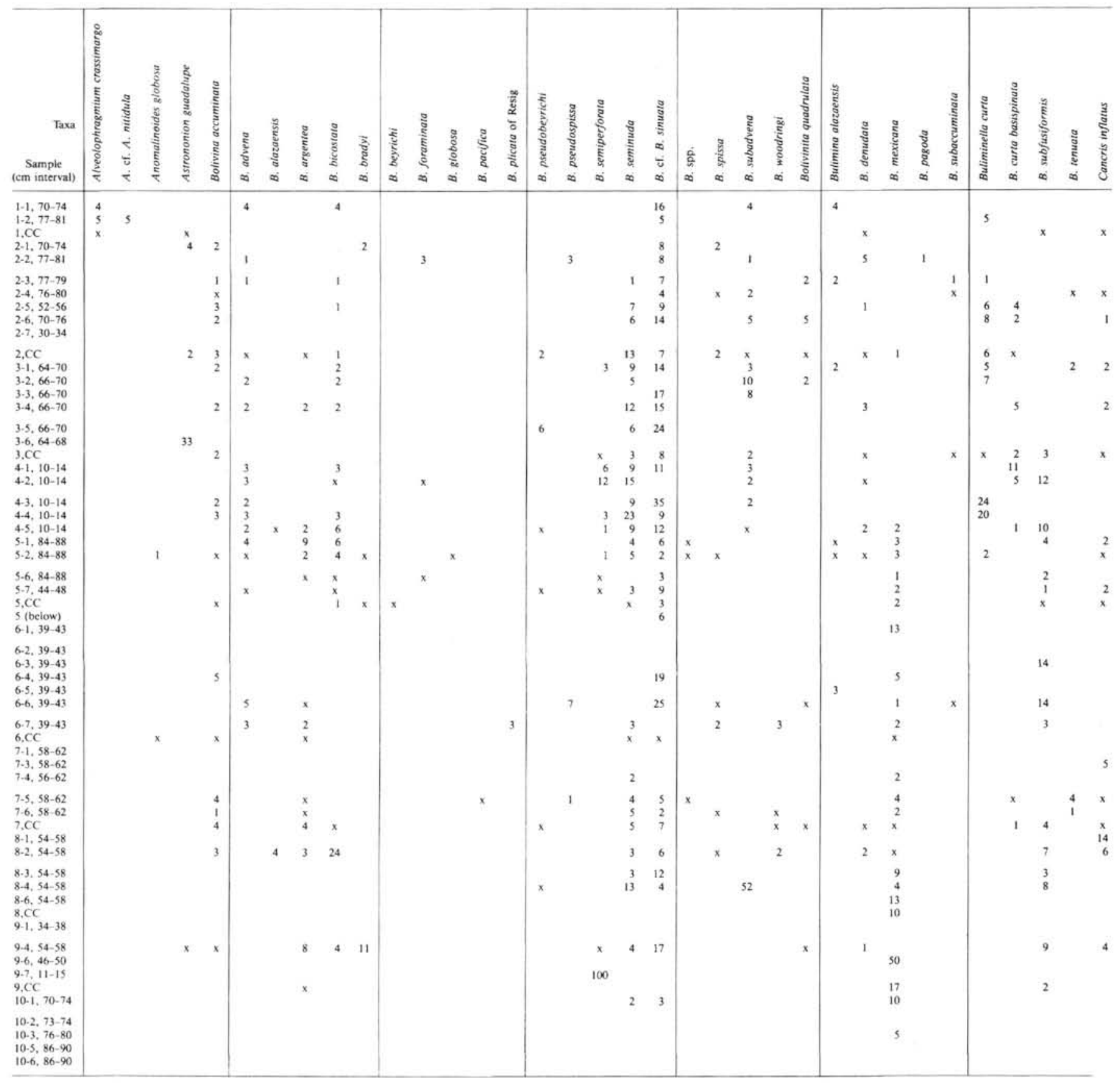

Note: Benthic foraminiferal occurrences are given as percent total fauna; an $x$ indicates less than $1 \%$. Biofacies abundances are also given in percent total fauna; $1 \mathrm{~S}=$ inner shelf; $\mathrm{OS}=$ outer shelf; $\mathrm{UB}=$ upper bathyal; $\mathrm{O}_{2}$ $=$ oxygen minimum zone; $\mathrm{UMB}=$ upper middle bathyal; $\mathrm{LMB}=$ lower middle bathyal; $\mathrm{LB}=$ lower bathyal; $\mathrm{A}=$ abyssal; dot or blank space indicates species is not present. 
Table 3. (Continued).

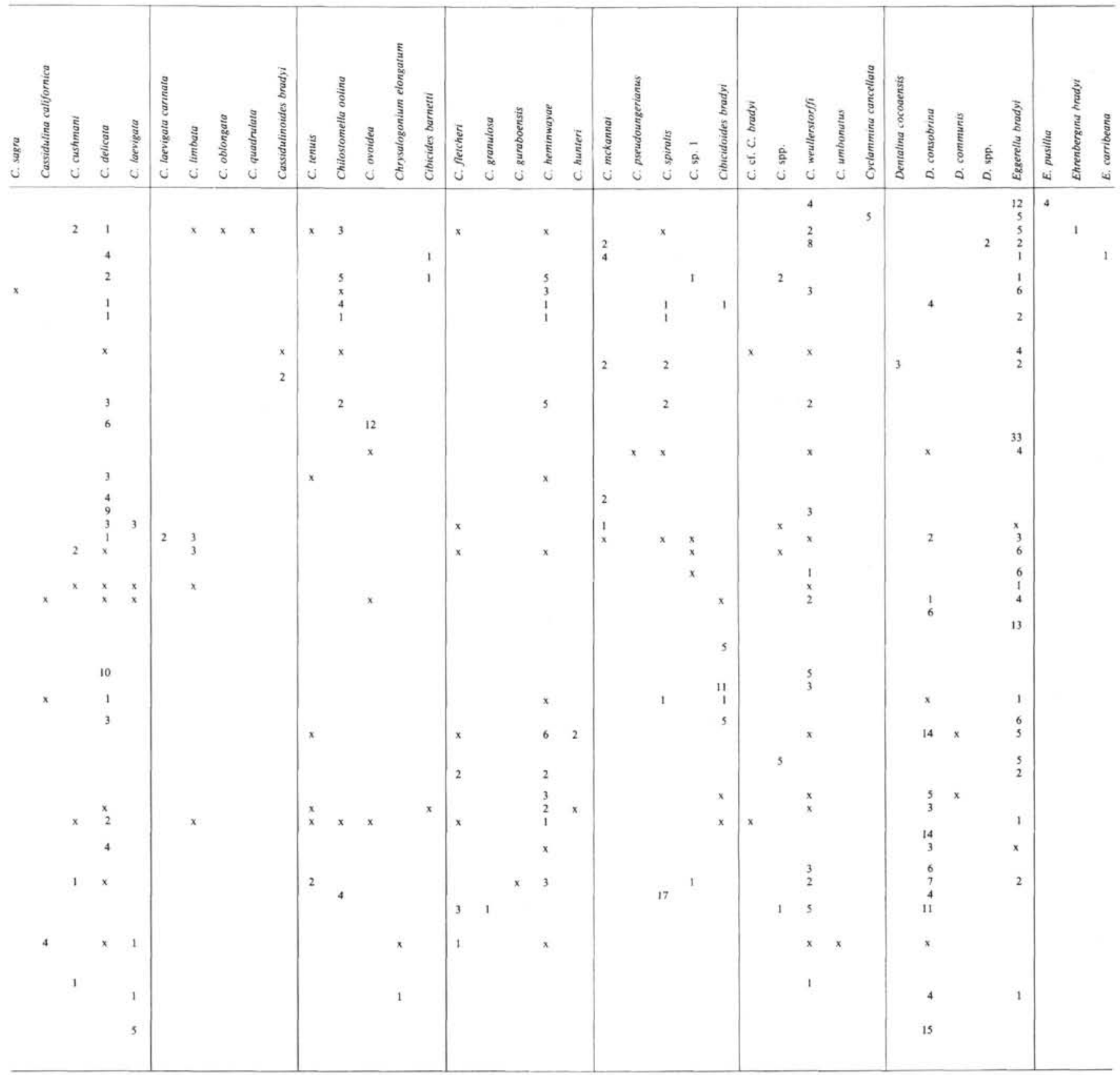


Table 3. (Continued).

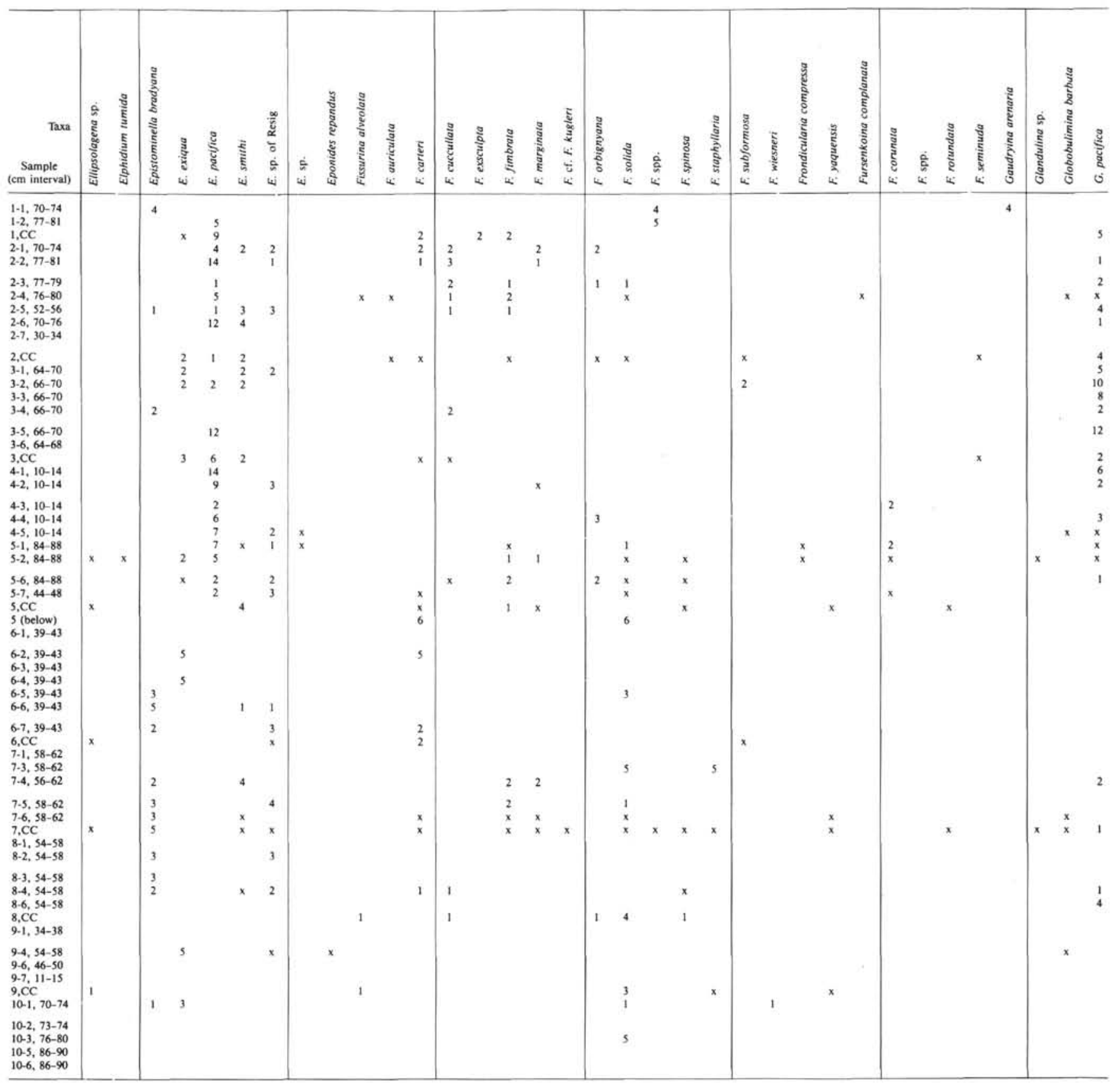


Table 3. (Continued).

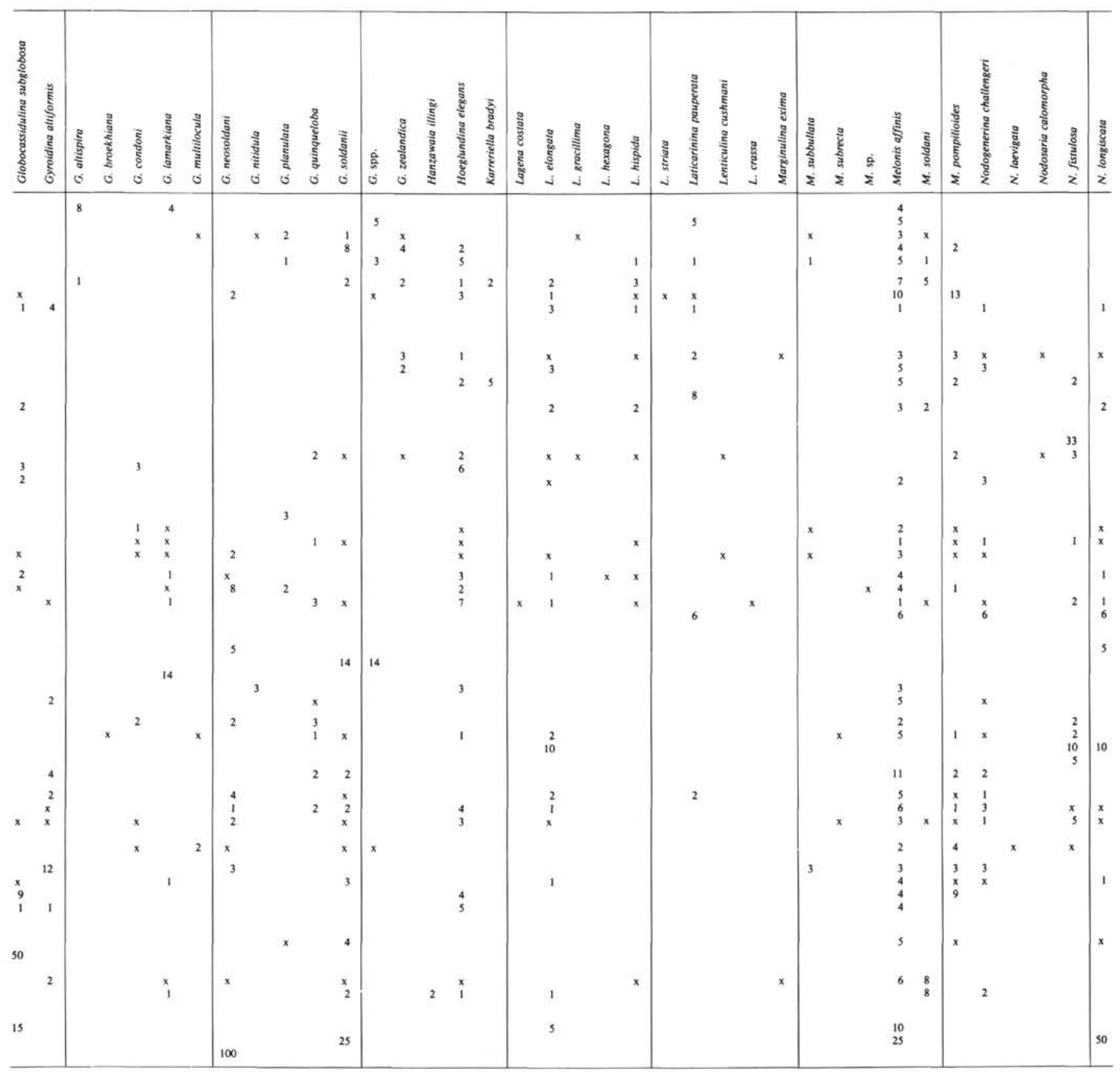


Table 3. (Continued).

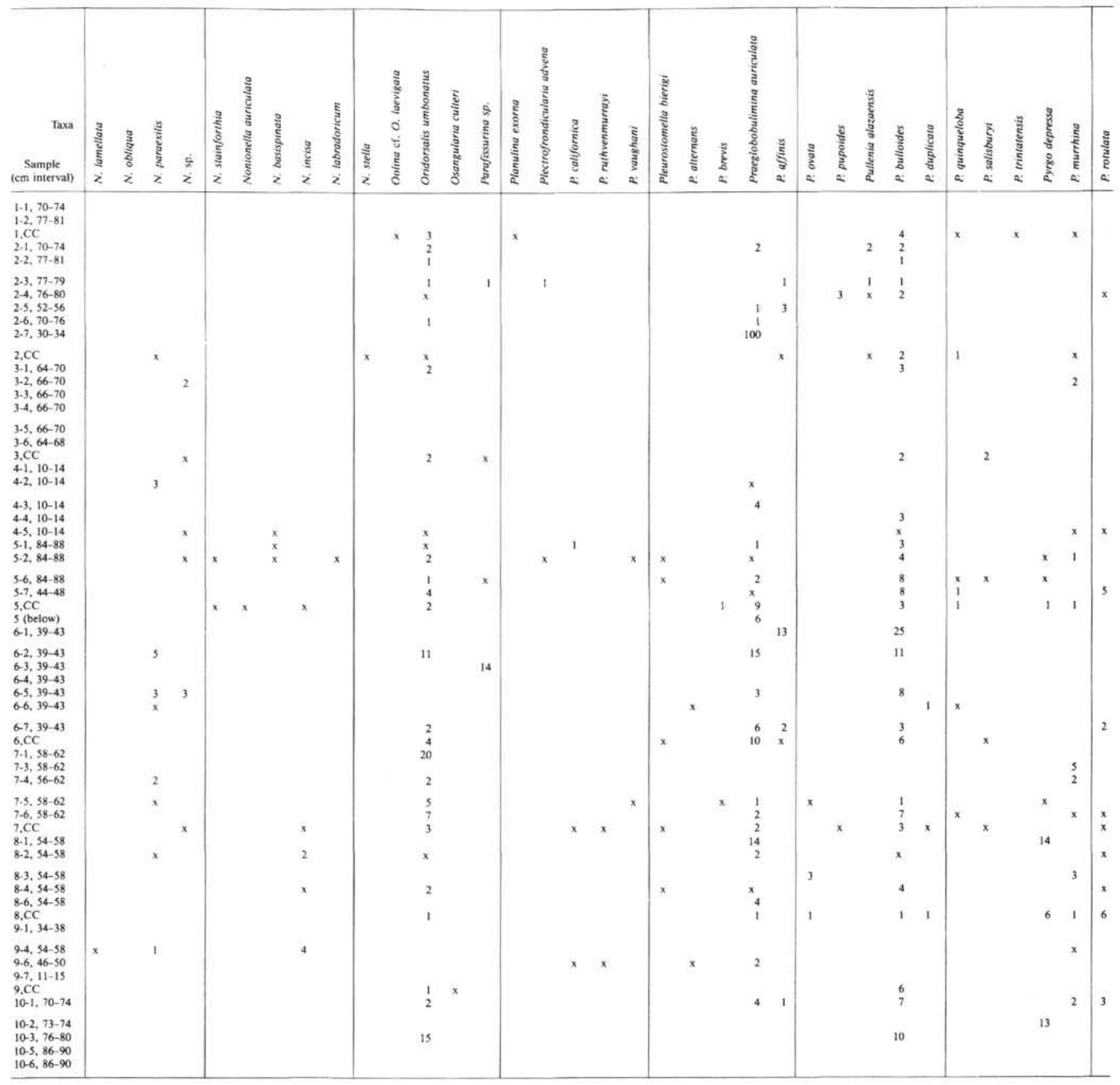


Table 3. (Continued).

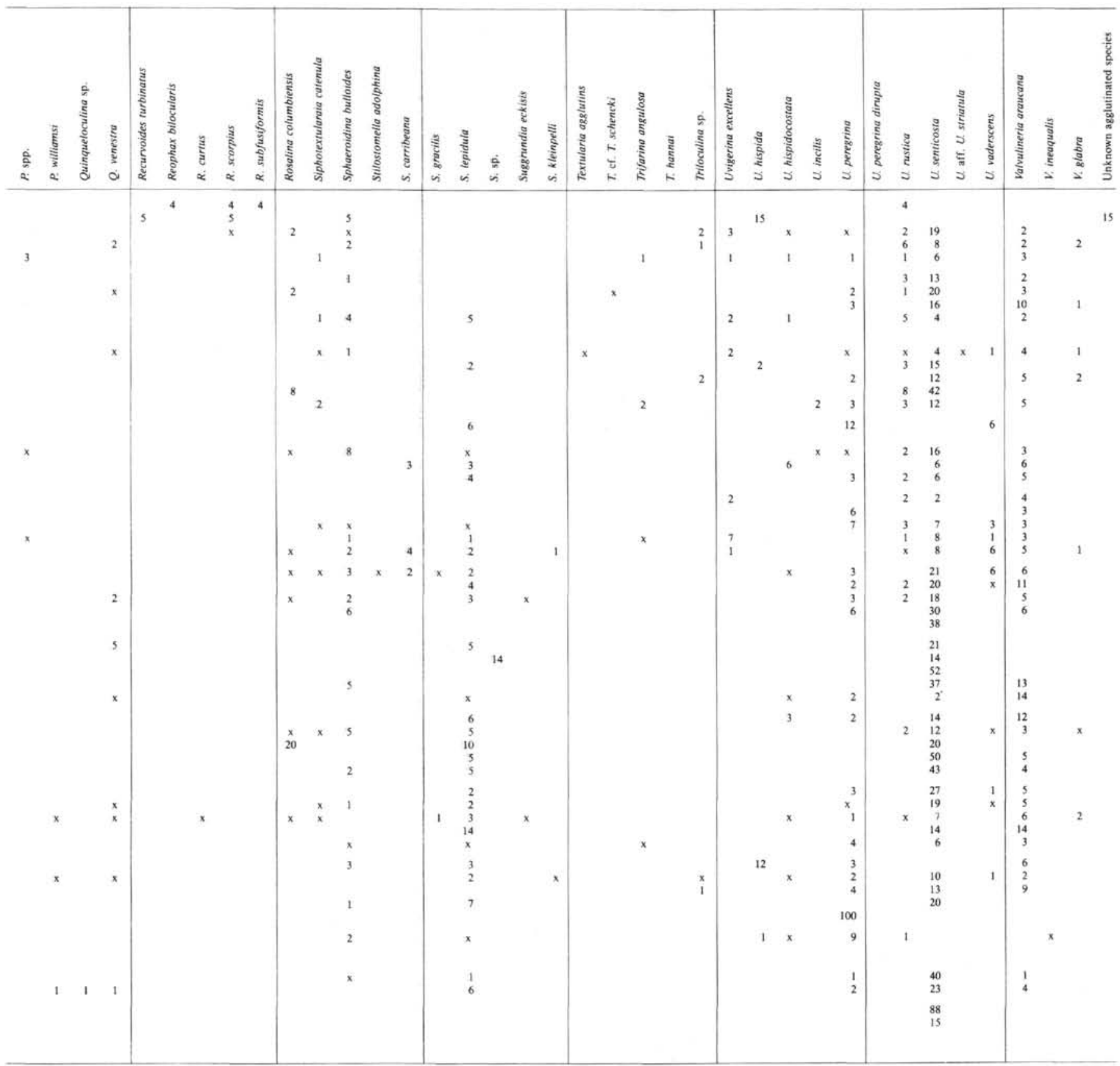


Table 3. (Continued).

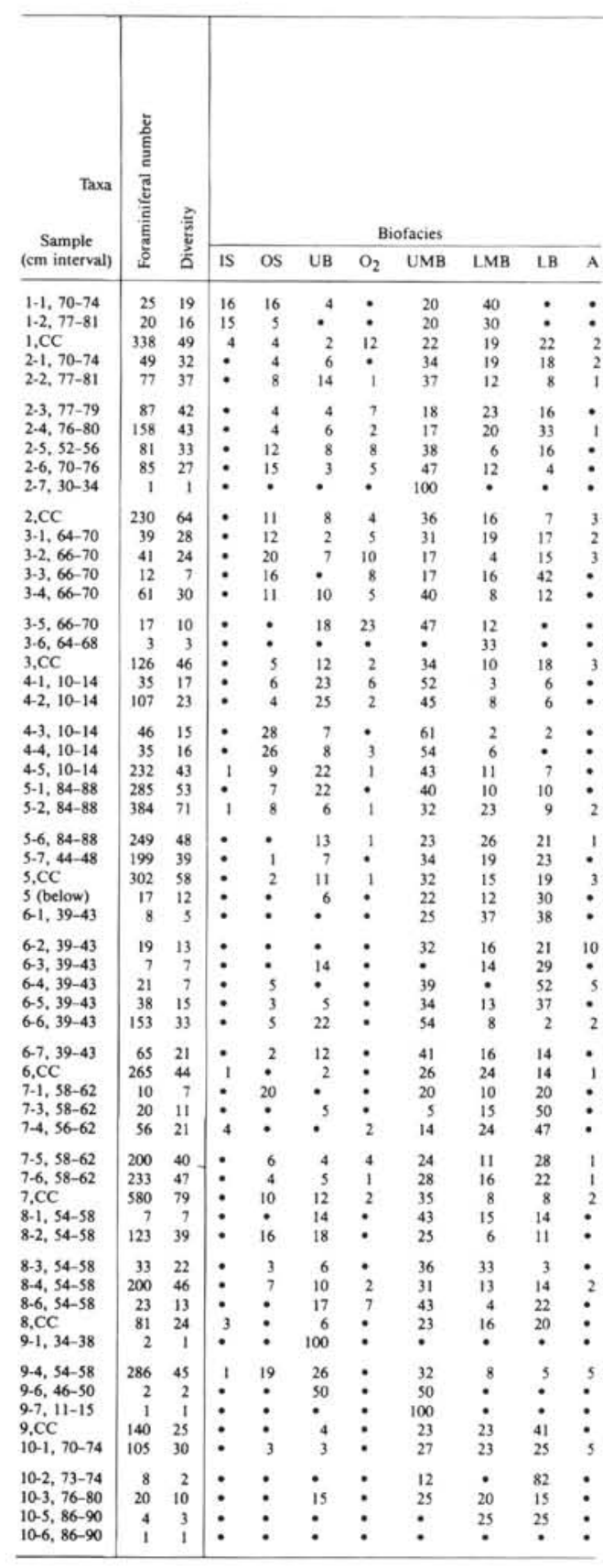

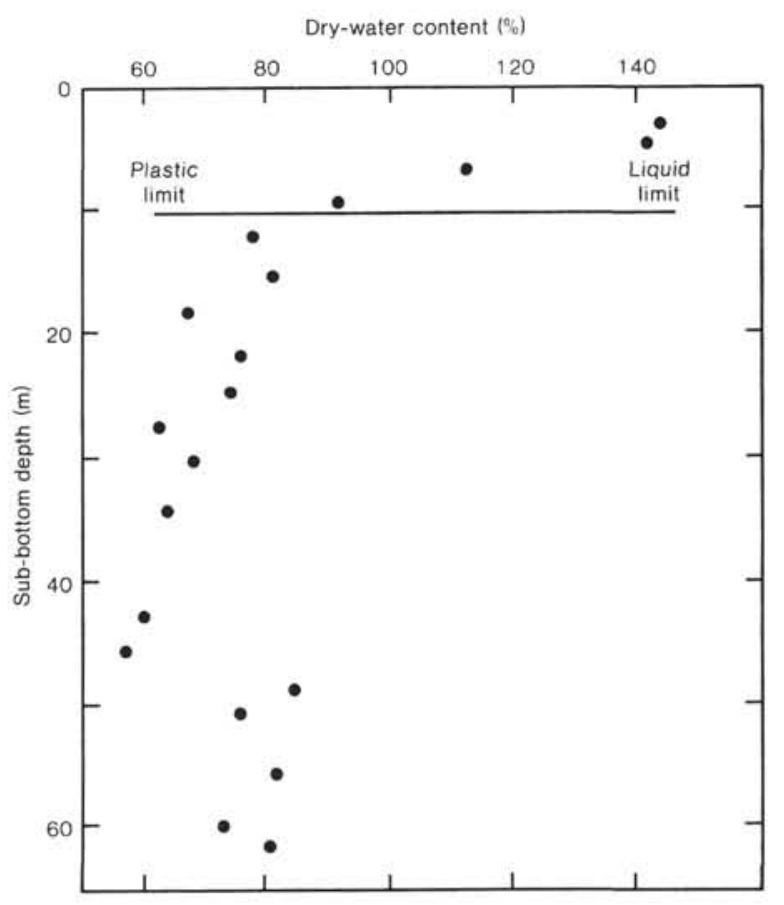

Figure 9. Comparison of natural water content of sediments of Site 565 to liquid and plastic limits of Section 565-1-4.

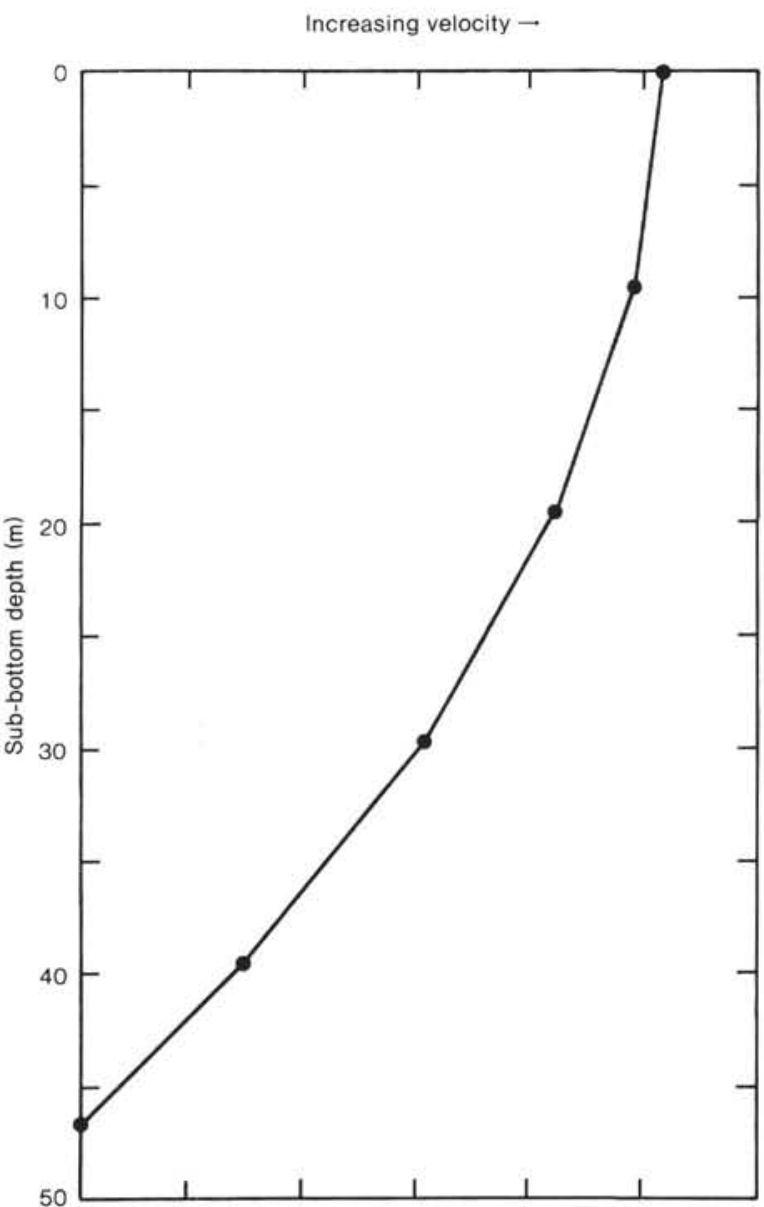

Figure 10. Calculated downslope velocity profile for potential creep for sediments in the upper $\mathbf{4 7} \mathrm{m}$ at Site 565 . 